Illinois State University

ISU ReD: Research and eData

Theses and Dissertations

$4-10-2020$

\title{
A Comparison Between General And Special Educators: Elementary Teachers' Efficacy For Teaching Students With Disabilities
}

Morgan E. Johnson

Illinois State University, mjohnson0896@gmail.com

Follow this and additional works at: https://ir.library.illinoisstate.edu/etd

Part of the Psychology Commons

\section{Recommended Citation}

Johnson, Morgan E., "A Comparison Between General And Special Educators: Elementary Teachers' Efficacy For Teaching Students With Disabilities" (2020). Theses and Dissertations. 1335.

https://ir.library.illinoisstate.edu/etd/1335

This Thesis is brought to you for free and open access by ISU ReD: Research and eData. It has been accepted for inclusion in Theses and Dissertations by an authorized administrator of ISU ReD: Research and eData. For more information, please contact ISUReD@ilstu.edu. 


\section{A COMPARISON BETWEEN GENERAL AND SPECIAL EDUCATORS: ELEMENTARY TEACHERS' EFFICACY FOR TEACHING STUDENTS WITH DISABILITIES}

\section{MORGAN E. JOHNSON}

\section{Pages}

The Individuals with Disabilities Education Act (2004) is a U.S. federal law that promotes an inclusive model of classroom participation. In this model, the goal is that all children, regardless of disability status, learn together while receiving high quality instruction and developing positive social relationships with peers. With the rise of inclusive education, more and more students with disabilities are receiving instruction in the general education classroom. Thus, it is pertinent that general educators feel confident in their abilities to effectively teach students with disabilities. Unfortunately, research has demonstrated that general education teachers have a low sense of teacher efficacy for teaching students with disabilities, in part due to a lack of education, experience, and support. Acknowledging the importance of teacher efficacy and the role it plays in children's academic success, this study attempted to analyze elementary teacher efficacy in multiple domains. First, teachers in my sample reported relatively high efficacy related to students with disabilities, but general educators reported lower efficacy than special educators. In addition, this study found that general educators reported higher overall efficacy scores in teaching students in general than teaching students with disabilities. Lastly, this study attempted to better understand the construct of teacher efficacy and found that special educators reported higher levels of efficacy-related details such as education, experience, and support. Implications for the field of education are discussed.

KEYWORDS: teacher efficacy; students with disabilities; elementary education; IDEA; inclusion 


\section{A COMPARISON BETWEEN GENERAL AND SPECIAL EDUCATORS: ELEMENTARY}

TEACHERS’ EFFICACY FOR TEACHING STUDENTS WITH DISABILITIES

MORGAN E. JOHNSON

A Thesis Submitted in Partial

Fulfillment of the Requirements

for the Degree of

MASTER OF SCIENCE

Department of Psychology

ILLINOIS STATE UNIVERSITY 
(C) 2020 Morgan E. Johnson 


\section{A COMPARISON BETWEEN GENERAL AND SPECIAL EDUCATORS: ELEMENTARY}

TEACHERS’ EFFICACY FOR TEACHING STUDENTS WITH DISABILTITIES

MORGAN E. JOHNSON

COMMITTEE MEMBERS:

Alycia M. Hund, Chair

Adena B. Meyers 


\section{ACKNOWLEDGMENTS}

First of all, I would like to thank my committee members, Dr. Alycia Hund and Dr. Adena Meyers, who worked tirelessly to help me complete this thesis. Although much of the final writing and analyses were done during the COVID-19 crisis, Dr. Hund was always available for Zoom meetings and quickly turned around edits. Dr. Meyers was incredibly helpful in navigating the statistics associated with this project and asked some big question ideas that truly expanded the discussion section. I would also like to thank Dr. Alycia Hund's research lab for their assistance in collecting participants. Additionally, I would like to recognize the individuals in the School Psychology program at Illinois State University, especially my cohort members. These individuals have been a tremendous source of support throughout this entire process. They were always around to discuss ideas and provide recommendations and were there to celebrate the finalization of this thesis despite not being able to celebrate in-person. Lastly, I would like to thank my friends and family for being a constant source of love and support. I was able to obtain many participants through their sharing of my social media link and they were always asking for updates regarding my progress. The culmination of this project would not have been possible without the support of the people listed above.

M.E.J 


\section{CONTENTS}

ACKNOWLEDGEMENTS

TABLES

CHAPTER I: THE PROBLEM AND ITS BACKGROUND 1

Statement of the Problem 1

CHAPTER II: REVIEW OF THE LITERATURE

History of Disability Law 3

Separation of General and Special Education $\quad 4$

$\begin{array}{ll}\text { Special Education Teachers } & 4\end{array}$

General Education Teachers 5

Teacher Efficacy $\quad 6$

$\begin{array}{ll}\text { Teacher Education } & 7\end{array}$

$\begin{array}{ll}\text { Pre-Service Education } & 7\end{array}$

$\begin{array}{lr}\text { In-Service Education } & 10\end{array}$

$\begin{array}{ll}\text { Teacher Experience } & 11\end{array}$

$\begin{array}{ll}\text { Teacher Support } & 13\end{array}$

Attitudes on Inclusion $\quad 16$

Research Questions and Hypotheses $\quad 18$

$\begin{array}{ll}\text { CHAPTER III: METHOD } & 20\end{array}$

$\begin{array}{ll}\text { Participants } & 20\end{array}$

$\begin{array}{ll}\text { Measures } & 21\end{array}$

$\begin{array}{ll}\text { Teacher Self Efficacy Scale (TSES) } & 21\end{array}$ 
Experience Related to Teaching Students with Disabilities 23

$\begin{array}{ll}\text { Procedure } & 24\end{array}$

CHAPTER IV: RESULTS 25

$\begin{array}{ll}\text { Analysis } & 25\end{array}$

$\begin{array}{ll}\text { Research Question } 1 & 25\end{array}$

Research Question $2 \quad 26$

$\begin{array}{ll}\text { Research Question } 3 & 27\end{array}$

$\begin{array}{ll}\text { Education } & 27\end{array}$

$\begin{array}{ll}\text { Experience } & 28\end{array}$

$\begin{array}{ll}\text { Support } & 30\end{array}$

Open Ended Probes $\quad 31$

CHAPTER V: DISCUSSION 33

$\begin{array}{ll}\text { Implications for Practice } & 38\end{array}$

$\begin{array}{ll}\text { Limitations and Future Directions } & 42\end{array}$

$\begin{array}{ll}\text { Sample } & 42\end{array}$

Self-Report 43

$\begin{array}{ll}\text { Sampling Bias } & 43\end{array}$

$\begin{array}{ll}\text { Measures } & 43\end{array}$

Predictive Modeling 44

$\begin{array}{ll}\text { Conclusion } & 45\end{array}$

$\begin{array}{ll}\text { CHAPTER VI: TABLES } & 47\end{array}$

$\begin{array}{lc}\text { REFERENCES } & 64\end{array}$ 


\section{TABLES}

Table

Page

1. Descriptive Information for Overall Sample 47

2. Teaching Students with Disabilities Efficacy Scale (TSDES) Scores by Teacher Type 49

3. Comparison of Raw Efficacy Scores for General Educators 50

4. Descriptive Information for Education Variables 51

5. Descriptive Information for Experience Variables 53

6. Mean Comfort Level with IDEA Disability Categories by Teacher Type 59

7. Descriptive Information for Support Variables 60

8. Mean Frequency of Collaboration by Teacher Type 61

9. Open Ended Responses 62 


\section{CHAPTER I: THE PROBLEM AND ITS BACKGROUND}

\section{Statement of the Problem}

The Individuals with Disabilities Education Act (IDEA) is a U.S. federal law passed in 1997 and reauthorized in 2004 [Individuals with Disabilities Education Improvement Act (IDEIA)] that promotes an inclusive model of classroom participation. In this model, all children, regardless of disability status, learn together in the general education classroom, receiving high quality instruction and developing positive social relationships with peers. Historically, general education and special education were viewed as separate entities. Due to IDEA and the importance of educating children in the least restrictive environment, more and more students with disabilities are receiving instruction in the general education classroom. According to a survey completed by the National Center for Education Statistics (2017), in the Fall of 2014, $95 \%$ of students with disabilities, aged 6 to 21 years, were served in regular schools, and $62 \%$ of these students spent $80 \%$ or more of more of their day in a general education classroom. In the 2015-2016 school year, 34\% of students receiving services under IDEA were for specific learning disabilities, $20 \%$ for speech or language impairments, $14 \%$ for other health impairments (including Attention-Deficit/Hyperactivity Disorder), and 9\% for Autism Spectrum Disorders. The other $33 \%$ consisted of developmental delays, emotional disturbances, multiple disabilities, and other (U.S. Department of Education, 2017).

Overall, general education teachers play a primary role in the education of students with disabilities, and each student has individual learning needs. Thus, the need for educators to be prepared to teacher diverse learners has become a critical issue. In order to examine teachers' feelings of preparedness (efficacy) for undertaking this role three particular areas to target are 1) teacher education, 2) teacher experience, and 3) teacher support. 
Acknowledging the importance of teacher efficacy and the role it plays in children's academic success, this study served as an attempt to analyze elementary teacher efficacy in multiple domains. First, this study examined general educators' efficacy in teaching students with disabilities in comparison to special educators, who specialize in the teaching of diverse learners. In addition, this study examined whether general educators' efficacy differs for teaching students with disabilities in comparison to students in general. Lastly, this study attempted to better understand the construct of teacher efficacy and offer valuable information regarding related details such as education, experience, and support. 


\section{CHAPTER II: REVIEW OF THE LITERATURE \\ History of Disability Law}

Historically, children with disabilities were excluded from the public education system until the 1970s (Seligman \& Darling, 1997). In fact, before the passage of The Individuals with Disabilities Education Act (IDEA), originally known as The Education for Handicapped Children Act, in 1975, only one in five children with a disability attended public school in the United States. Amendments to The Education for Handicapped Children Act were passed in 1990 effectively changing the name to The Individuals with Disabilities Education Act (IDEA) (Aron \& Loprest, 2012). IDEA, amended again in 1997 and 2004 [as The Individuals with Disabilities Education Improvement Act (IDEIA)], is a groundbreaking federal law that mandates equity in the education of students with disabilities, establishing their right to attend public schools. IDEA uses a categorical definition of disability including the following: autism spectrum disorder (ASD), intellectual disability, deaf-blindness, deafness, hearing impairment, visual impairment including blindness, emotional disturbance, specific learning disability, other health impairment [including Attention-Deficit/Hyperactivity Disorder (ADHD)], speech or language impairment, orthopedic impairment, traumatic brain injury, or multiple disabilities.

IDEA has three key components. First, the act instituted free appropriate public education (FAPE) regardless of the severity of the disability. This indicates that services will be provided at no expense to the student's family. Second, it established individualized education plans (IEPs) to meet the unique needs of children with disabilities. IEPs are legal documents written for each child with a disability indicating present level of performance, goals and short-term objectives, progress and reporting requirements, services to be offered, general education involvement, and dates and times of services, to name a few (Gartin \& Murdick, 2005). Lastly, IDEA mandated 
that children be taught in the least restrictive environment (LRE) (Moores, 2011). The term least restrictive environment has been interpreted to mean the mainstreaming of children with disabilities into general education classrooms to the greatest extent possible. This method allows for students with and without disabilities to learn alongside their peers, fostering academic and socioemotional growth.

\section{Separation of General and Special Education}

According to a report by the President's Commission on Excellence in Special Education (2002), “children placed in special education are general education children first.” While general and special education are often viewed separately, the two share responsibilities for children with disabilities, including instruction. Unfortunately, teachers do not always view education in this manner, which is further perpetuated by schools and colleges of education that maintain separate programs. The mindset that we view teachers based on categories (e.g., bilingual, special education, general education) creates a barrier to properly preparing teachers to work with students from diverse populations. In addition, this reinforces the idea that certain students can only be taught by specific teachers; for example, the notion that special education students can only be taught by special education teachers (Blanton, Pugach, \& Florian, 2011). With the implementation of IDEA and the blurring of special and general education, this mentality is problematic.

\section{Special Education Teachers}

Special educators possess specialized knowledge in the education of students with disabilities, including learning, emotional, and intellectual disabilities, to name a few. First, special educators understand how exceptionalities can challenge the learning process and the ways in which this can be mitigated by modifying the learning environment. To elaborate, the 
special educator may design accommodations or modify the existing curriculum to better meet the needs of the student. In addition, the special educator has the knowledge of evidence-based instructional strategies to advance the learning of students with disabilities (American Academy of Special Education Professionals, 2006). With regard to behavior, special educators are considered experts in the use of behavior management strategies, particularly beneficial in times of crisis (Oliver \& Reschly, 2010). Furthermore, special educators are knowledgeable on disability law and the education system. In particular, special educators often serve as case managers who lead IEP teams (Council for Exceptional Children, 2015). Overall, the inclusionrelated knowledge possessed by a special educator is richer that of a general educator (Gehrke \& Cocchiarella, 2013). Although both types of educators have knowledge of teaching practices, special educators possess knowledge that would greatly benefit general educators (i.e., behavior modification and differentiating instruction), especially given the current state of our educational system and the federal laws (i.e., IDEA) put in place to ensure children with disabilities receive a quality education.

\section{General Education Teachers}

In contrast, general education teachers are prepared to teach students in the areas of reading, writing, science, history, and mathematics. These teachers are taught to attend to the social, emotional, and academic needs of their students in a classroom that may or may not include students with disabilities. While these teachers may have taken some classes on teaching students with disabilities, historically, students with disabilities have not been their primary focus. Rather, the focus has been on teaching typically developing children (Rosenzweig, 2009). Therefore, general education teachers do not receive extensive training on the implementation of 
an IEP, including differentiating instruction, behavior management, and special education law (Rosenzweig, 2009; O'Connor, Yasik, \& Horner, 2016).

\section{Teacher Efficacy}

The concept of teacher efficacy is rooted in the work of Albert Bandura's social cognitive theory. Bandura (1997) stated that self-efficacy refers to an individual's belief in his or her ability to perform to a certain level of attainment. It is important to note that self-efficacy is a belief, and beliefs do not always match actual capabilities. To elaborate, it is one thing to possess the knowledge and skills to complete a task, and another to feel confident in your abilities. According to Bandura's theory, these two components are of equal importance and contribute to successful functioning (Artino, 2012). Self-efficacy has important implications as it influences behavior, including how people feel, think, and motivate themselves. For example, someone with low self-efficacy may avoid a task, believing they are incapable, while someone with high selfefficacy may be more likely to engage with the task, believing they have the ability to be successful. Teaching is a difficult and stressful profession, but efficacy is a protective factor that can reduce the experience of job strain and likelihood of burnout (Schwarzer \& Hallum, 2008).

Similarly, teacher efficacy is defined as a teacher's belief in their ability to effectively teach and promote student engagement and learning (Tschannen-Moran \& Hoy, 2001). A literature review conducted by Tschannen-Moran and Hoy (2001) found that teacher efficacy has important implications for student success, including academic achievement and student selfefficacy. In addition, the researchers found that teacher efficacy also affects the effort teachers put into teaching, their willingness to meet the needs of their students, their persistence in face of difficulties, likelihood of referring difficult students to special education, and commitment and enthusiasm for teaching. Ultimately, teacher efficacy is an important construct, but there is an 
abundance of research describing general educators who do not feel confident in their abilities to effectively teach students with disabilities in the general education classroom (Blanton, L. P., Pugach, M. C., \& Florian, L., 2011; Buell et. al, 1999; Hussien and Qaryouti, 2015; Polou, 2005; Rosenzweig, 2009). The literature suggests three particular areas to target in order to increase teacher efficacy: 1) teacher education, 2) teacher experience, and 3) teacher support (deBettencourt, 1999; Leyser, Zeiger, \& Romi, 2011; Lohrman \& Bambara, 2006).

\section{Teacher Education}

Pre-Service Education. In order to become a professional teacher in any state, it is required that one receives state certification which can be achieved by acquiring a bachelor's degree in education. Over the course of four years, students complete coursework and participate in clinical experiences that contribute to their ability to make a positive difference in the lives of students (Blanton, Boveda, Munoz, \& Pugach, 2017). Programs accredited by The National Council for Accreditation of Teacher Education (NCATE), now known as The Council for the Accreditation of Educator Preparation (CAEP), are held in high regard and ensure students receive a well-rounded education. Any professional education program that is accredited by NCATE is required to comply with a number of standards, including Standard Number Four: Diversity. This standard requires preparation programs to ensure future educators are knowledgeable and prepared to work with diverse students, including students with exceptionalities (NCATE, 2008). In turn, many states mandate that teachers take one introductory special education course. A study conducted by Allday, Neilsen-Gatti, and Hudson (2013) found that in their sample of 109 universities across the U.S., approximately half of the course credits needed to earn a bachelor's degree were dedicated to teacher preparation.

However, only $7-10 \%$ of those credits were related to educating students with disabilities in the 
inclusive setting (i.e., characteristics of disabilities, differentiating instruction, behavior management, collaboration between general and special education). Furthermore, pre-service teachers in approximately one third of the programs sampled were not required to take an introductory level special education course, despite the NCATE standard indicating they must be informed about diversity. This is problematic because one course in special education can significantly improve attitudes towards inclusion and instructional competencies in teaching students with disabilities (Powers, 1992; Sharma \& Nuttal, 2016). To elaborate, a single course can reduce teachers' concerns regarding how inclusion will impact their teaching and their students' learning. While one course is beneficial, it does not mean that it is sufficient preparation. For example, a study conducted by Tournaki and Samuels (2016) tested the impact of inclusive education on teacher attitudes. Ninety-eight general and 76 special education master's students responded. The researchers found that one course in inclusive education is insufficient as attitudes toward inclusion initially increased throughout the course but returned to their initial level by the end of the program. Additionally, in some programs, the mandated course does not cover instructional strategies, and instead gives an overview of special education and the various laws associated with it (DeSimone \& Parmar, 2006).

Illinois State University's (ISU) College of Education ranks in the top 5 percent in the U.S. and has been continuously accredited by NCATE since 1954. In addition, ISU is the largest preparer of teachers in Illinois, as $87 \%$ of its public-school districts employ at least one ISU alum (Illinois State University, 2019). Given this leadership role, examining ISU's general educator course requirements is helpful in understanding best practices and trends. Upon analysis of the ISU course catalog, elementary education majors (B.S. in Education) are only required to take one special education course, SED 101: The Exceptional Learner. In this course students gain 
entry level knowledge of standards in special education and characteristics of students with disabilities (Illinois State University, 2019). More specifically, the course outlines important legislation, collaborative relationships with school staff and families, and differentiating instruction, to name a few themes. Although this course is beneficial, again, it may not be enough. The purpose of this course is entry-level knowledge, indicating the need for future classes. Students are also required to choose a 12-hour elective track from the following options: English as a second language, reading teacher, special education, or diverse learner (Illinois State University, 2018). This is certainly a step in the right direction with regard to further preparing teachers, but students are still given an option, resulting in the possibility that students may not receive enough instructional time in order to feel efficacious with teaching students with disabilities.

A study by Gao and Mager (2011) tested the effectiveness of an inclusive teacher preparation program at a private university accredited by the NCATE. The goal of this study was to assess how pre-service teachers' sense of efficacy and attitudes towards diversity shift over the course of the preparation program. The program promoted diversity by fostering collaboration and the idea that all children are capable of learning. Pre-service teachers $(N=168)$ took multiple special education classes, including specific inclusive education classes. In addition, they were required to have multiple fieldwork experiences exposing them to general education classrooms and students with disabilities. Ultimately, this inclusive teacher education program integrated coursework and practicum experiences in order to better prepare pre-service teachers to teach a diverse group of students. In order to analyze teacher efficacy, this study utilized a self-report scale developed by Gibson and Dembo (1984) assessing Personal Teaching Efficacy (PTE) (i.e., a teacher's belief in their ability to personally impact student learning) and General 
Teaching Efficacy (GTE) (i.e., a teacher's general confidence in their profession's ability to impact student learning). With regard to assessing attitudes towards inclusion, the researchers utilized another self-report scale, the Attitudes Toward Inclusive Education Scale (ATIES). Results found that PTE and GTE demonstrated different developmental patterns, with PTE being more linear and GTE varying based on particular learning experiences. The researchers described that GTE may be context-dependent and more impacted by challenging experiences with students. In contrast, PTE may be more individual and grow with more rigorous training and experiences working with children with disabilities. Additionally, attitudes toward students with disabilities were positive, with more favorable attitudes towards the inclusion of students with social disabilities relative to students with behavioral disabilities. Overall, the findings were positive, suggesting that a teacher preparation program that focuses more on diversity can improve teacher efficacy and promote positive attitudes towards inclusion.

In-Service Education. Numerous studies have demonstrated the importance of professional development for teachers and staff in supporting teacher efficacy. The primary purpose of professional development is to ensure that teachers continue to strengthen their skills in order to most effectively meet the needs of their students. The Illinois State Board of Education (ISBE) requires that licensees complete 120 hours of professional development every five year renewal cycle, which equates to an average of 24 hours per year (n.d.). Schools are allotted up to four teacher institute days which can be used for the purpose of professional development (Illinois State Board of Education, June, 2019). Educators can also privately seek out professional development, and some school districts provide reimbursement for the associated fees (Corcoran, 1995). 
In a study conducted by Buell et al. (1999), a survey was distributed to 289 teachers (202 general educators and 87 special educators) to gain information regarding teachers' confidence regarding student success, teachers' in-service needs, and perceptions of necessary program support in inclusive settings. The researchers found that $78 \%$ of general education teachers reported needing but not receiving any type of in-service training related to inclusion. Teachers' descriptions of specific training needs included modifying and adapting curriculum, progress monitoring, behavior management, developing IEPs, and using assistive technology. Another study conducted by Brownell and Pajares (1999) distributed a survey instrument to 128 general education teachers and found that general education teachers viewed inclusion as more successful after receiving in-service professional development. Specifically, teachers expressed that they greatly benefited from information about the needs of students with disabilities, curriculum and instructional adaptations, and behavior management techniques. Adapting materials and differentiating instruction is extremely important because one size fits all does not fit when instructing diverse learners. It is critical that teachers adjust the curriculum to meet the needs of the student, rather than expecting the student to conform to the curriculum (Hall, Strangman, \& Meyer, 2009). Studies have found that the more hours of professional development teachers acquired, the more they believed they were able to adapt instruction for students with IEPs (Dixon, McConnell, \& Hardin, 2014). A study conducted by Kosko and Wilkins (2009) found that any amount of professional development is beneficial, but 8 or more hours demonstrated the largest effect, which was more than twice the effect of less than 8 hours.

\section{Teacher Experience}

Prior experience working with children with disabilities has been demonstrated to have a profound impact on teacher efficacy. Numerous studies have highlighted the need for fieldwork 
experiences working with students with disabilities during professional preparation, as these applied experiences are associated with higher levels of self-efficacy (Leyser et. al, 2011; BrayClark \& Bates, 2003; Burke \& Sutherland, 2004; Able et. al, 2015). Knowledge is best cultivated through experience, as details acquired through coursework and professional development are translated into practice. Fieldwork placements offer pre-service teachers the opportunity to develop efficacy through mastery experiences and self-evaluation of strengths and weaknesses (Burke \& Sutherland, 2004). To elaborate, hands-on experiences with children with disabilities provides pre-service teachers with successful teaching strategies and a sense of competence with adapting activities and modifying curriculum, therefore contributing to positive attitudes towards inclusion (Leatherman \& Niemeyer, 2005; Frankel, Hutchinson, Burbidge, \& Minnes, 2014). Furthermore, Leyser et. al (2011) found that non-course related experiences, including mentoring, tutoring, and working at summer camps, also were associated with higher levels of self-efficacy. Other types of non-course related experiences include having a family member with a disability and volunteer or work experience (Burke \& Sutherland, 2004).

Additionally, experience with behavior management strategies has been found to be helpful in reducing problem behaviors in the classroom, as well as promoting positive teacher efficacy. Many teachers express concerns regarding students' problem behaviors (e.g., refusal to do work, hitting, biting, aggression towards students and staff) due to a lack of prior experience. According to a study conducted by Alvarez (2007), teachers view children who exhibit problem behaviors as more challenging to work with, in comparison to students with disabilities that manifest academically rather than behaviorally (i.e., learning disorders). In fact, children with disabilities exhibit problem behaviors more than three times as often as otherwise-comparable, nondisabled peers (Hemmeter et al. 2006). These types of behaviors can lead to teachers feeling 
overwhelmed, especially if teachers are unaware of behavior management techniques. Another study, conducted by Lohrman and Bambara (2006), consisted of qualitative interviews with 14 general education teachers who had a least one student in their classroom with an identified disability. The researchers found that many teachers were apprehensive about including students with intense behavior needs, stemming from a lack of experience and training and also hearing other teachers describe the student as "violent" or "disruptive." These students acquired a negative reputation that followed them from one teacher to the next, perpetuating the preconceived notion that this child would be too difficult to manage. In turn, teachers expressed concerns about whether the children's behaviors would disrupt their classroom dynamic so much as to take away their attention from the rest of the class. On the contrary, teachers who had prior experiences managing problematic behaviors found that their students' behavioral needs were not beyond their ability.

\section{Teacher Support}

The support that teachers receive from their staff team and student families in meeting the needs of students with disabilities has been tied to teacher efficacy. Lohrman and Bambara (2006) found that the teachers viewed in-class support personnel (i.e., paraprofessionals or special education teachers) as an invaluable asset, most beneficial when they blended into the classroom as to not give away with whom they were there to work. Class support personnel assisted teachers with adapting materials, implementing behavior management techniques, and offering one-to-one assistance with the target student(s). Many teachers indicated that it would have been extremely difficult to formulate and implement behavior management strategies on their own. Collaboration is a common strategy described by many general education teachers across numerous studies. Specifically, teachers stressed the importance of collaboration between 
general and special education teachers, school counselors, school psychologists, and parents. The primary reasoning behind this need for collaboration is the specialized expertise and ability to offer suggestions that comes from team members with different training and experiences (Able et al., 2015). For example, special education teachers can distribute information sheets to general education teachers that describe specific characteristics of students, including strengths and weaknesses, and offer teaching strategies consistent with the accommodations outlined in the IEP. In addition, IEP fact sheets are also useful as they highlight the necessary components, including goals, accommodations, and reinforcers, ensuring the IEP is being properly implemented (Da Fonte \& Barton-Arwood, 2017).

Furthermore, home-school communication and collaboration are important avenues in which teacher efficacy is fostered. Parents are important stakeholders in the education process as they know their child best and can offer invaluable information about family goals, routines, resources, and stressors. When writing an IEP, it is important to utilize parents to help identify the purpose of behaviors, effective strategies to reduce problem behaviors, and students' strengths, weaknesses, likes, and dislikes. A quality intervention fits the needs of the child as well as the family (Fettig, Schultz, \& Ostrosky, 2013). Thus, it is critical to consider the opinions of family members, especially since they are involved in the implementation process and are members of the IEP team who participate in all aspects of the IEP process. Ultimately, when parents and teachers collaborate and communicate effectively, they can build a shared understanding about a student's academics, behaviors, and goals. In addition, teachers noted that parental feedback is important as it is reassuring to know parents believe they are doing a great job, in turn increasing teacher efficacy (Lohrman \& Bambara, 2006). 
School psychologists also offer unique expertise in collaborating with teachers, parents, and students to improve the educational and social-emotional needs of students. As such, school psychologists are a great resource and avenue of support for teachers. One of the roles of a school psychologist is serving as a part of the IEP team, given school psychologists' training in progress monitoring, interventions, assessment, and data collection and analysis. Additionally, school psychologists serve as consultants. School consultation is the provision of indirect psychological and educational services in order to improve the learning of a student or group of students (Gutkin, 2009). Often school psychologists meet with teachers who have concerns regarding a student with or without an IEP. In order to assist the student, the two collaboratively engage in the problem-solving process: defining the problem, selecting and designing an intervention, implementing the treatment plan with integrity, and assessing its effectiveness. Research has shown that consultation can successfully increase teachers' self-efficacy and provide teachers with the tools they need to be successful, in addition to suggestions they may not have previously considered (Gutkin, 2009). A study by Ponti and Curtis (1984) found a significant increase in teacher's expectation for success in dealing with students' problems after only three weeks of working with a consultant. For example, one of the major challenges teachers face is classroom management. As previously discussed, teachers do not receive much, if any, training on behavior modification, and low levels of teaching-efficacy have been linked to an increase in difficulty with handling student behavior (Stronge, 2018). Therefore, a school psychologist has a very important role in assisting teachers in the development of effective techniques to modify behavior through changing classroom contingencies of reinforcement (Meyers, 1973). 
Another key element of consultation is a school psychologists' ability to challenge deficit thinking. Deficit thinking is defined as the notion that students with disabilities struggle in school because they have disabilities. It situates school failure within the individual, rather than recognizing the "social ecology of the school, grade, or classroom" (Weiner, 2006). For example, a student who demonstrates hyperactivity is often immediately referred for an ADHD evaluation, overlooking the fact that hyperactivity can be developmentally appropriate for a kindergartener, especially if they were not allotted an opportunity to expel their energy (e.g., gym and recess). Thus, a school psychologist, who has expert knowledge on cases such as these, is a great resource for teachers and can help reframe behaviors in a positive manner and focus on the strengths of the child, rather than focusing only on deficits. In conclusion, research has demonstrated that teachers report having less support than they need to appropriately teach students with disabilities in the general education classroom.

\section{Attitudes on Inclusion}

A lack of teacher efficacy results in teachers being concerned about not being able to foster a positive learning environment for children with disabilities. In turn, this has a negative impact on how teachers view inclusion (Buell, Hallam, Gamel-McCormick, \& Scheer, 1999). In order for inclusion to be successful, teachers have to believe that it will work. When teachers feel confident about themselves and their ability to teach students with disabilities, then their views on inclusion are more positive (Montgomery \& Mirenda, 2014; Wilkins \& Nietfeld, 2004). On the other hand, when teachers feel negatively about their abilities, then they question their skills and their ability to make inclusion work in their classrooms.

Buell et al.'s (1999) study of 289 general and special educators found that general educators rated their understating of inclusion and their abilities to motivate students lower than 
did special educators. To elaborate, special educators demonstrated greater confidence and preparedness in meeting the needs of special education students in an inclusive setting. In addition, a study by deBettencourt (1999) concluded that $60 \%$ of the general education teachers surveyed did not support mainstreaming or had no strong feelings about it. These teachers did not believe that inclusion was successful in their school in regard to social and academic achievement. These findings illustrate that there is a strong and positive relationship between understanding inclusion and a teacher's belief that they can positively influence their students. If teachers do not understand inclusion and do not believe that they can be of any help, then they do not see the numerous benefits of inclusive education.

Under IDEA, parents have the right to be involved in their child's entire special education process including referral, testing, program planning, placement, and program evaluation. In general, parents are very supportive of the inclusion process, recognizing the social and academic benefits of learning in the general education classroom (Swedeen, 2009). Nonetheless, parents have expressed concerns regarding the quality of instruction their children receive. Specifically, concerns centered around the belief that special education teachers are more educated in teaching students with disabilities. In addition, parents of children with mild disabilities, in comparison to moderate to severe disabilities, held more positive views regarding inclusion (Leyser \& Kirk, 2004). Overall, parents echo many of the concerns brought forward by general education teachers regarding the benefits of inclusion and their belief in its ability to be successful when done well.

Overall, teacher efficacy is an important construct as it has implications for student success, including academic achievement and student self-efficacy. Additionally, efficacy affects the effort teachers put into teaching, their willingness to meet the needs of their students, their 
persistence in face of difficulties, the likelihood of referring difficult students to special education, and their commitment and enthusiasm for teaching (Tschannen-Moran \& Hoy, 2001). Despite its importance, research has demonstrated that general education teachers do not feel fully confident in their abilities to effectively teach students with disabilities in the general education classroom, as demonstrated by a low sense of teacher efficacy, in part due to a lack of education, experience, and support. This study aimed to further understand the construct of teacher efficacy by comparing general and special educators' efficacy for teaching elementary students with disabilities with implications for pre-service and in-service needs including education, experience, and support.

\section{Research Questions and Hypotheses}

This study addressed the following questions:

Research Question 1: Are general education teachers less efficacious in teaching students with disabilities, in comparison to special educators?

Hypothesis 1: Special educators would demonstrate higher levels of self-efficacy in teaching students with disabilities than will general education teachers, given their specialized training.

Research Question 2: For general educators, how does efficacy differ in teaching students with disabilities in comparison to teaching students in general?

Hypothesis 2: General educators would be more efficacious in teaching students in general, compared to teaching students with disabilities.

Research Question 3: What factors might be related to teacher efficacy?

Hypothesis 3: I sought qualitative details about the ways in which education, experience, and support might be related to teacher efficacy. 
This study was broad in its exploration of teacher efficacy. Although there is research assessing general education teachers' efficacy in teaching students with disabilities, much of the research was published in the early 2000s-2010s and has yet to influence change in the training of general education teachers. Additionally, newer research has attempted to develop efficacy scales that are more specific to teaching students with disabilities, demonstrating that self-efficacy for teaching generally and for teaching students with disabilities are two distinct constructs (Dawson $\&$ Scott, 2013). Given these scales are newly developed and have yet to acquire a large literature base, they required future research and validation. In this study, I examined teacher efficacy with regard to both general and special educators in the elementary setting, with hope of setting the stage for future studies to uncover the mechanisms by which teacher efficacy is cultivated. This study offered further insight into the necessary changes needed in the educational system in order to ensure teachers are efficacious in their ability to teach students with disabilities in the general education classroom. 


\section{CHAPTER III: METHOD}

\section{Participants}

The participants in this study were 1) general education teachers and 2) special education teachers from public elementary schools (PK-6) across the state of Illinois. In Illinois, a special education teacher is referred to as a Learning Behavior Specialist 1 (LBS1) (Illinois State Board of Education, 2019). The criteria for participation for teachers was having included, in the past three years, a student with an identified disability in his or her classroom. Student disability status was defined by the presence of an IEP on file at the school. This study originally aimed for a sample size of 200 in total. Recognizing that the number of general education teachers would most likely exceed the number of special education teachers throughout the state (i.e., $70 \%$ general educators, 30\% special educators [Buell et. al, 1999]), I aimed for 60 special education teachers and 140 general education teachers. In total, 244 surveys were returned; of these, 176 were sufficiently complete to be included in the sample. Surveys were determined to be sufficiently complete if teacher type was reported (general educator or special educator) and both efficacy scales were completed. Of the 68 incomplete responses, 28 participants were excluded for not reporting their teacher type, which was the third question on the survey, and 40 participants were excluded for not completing both efficacy scales. Upon analysis of the 176 responses, data from three participants were removed from analyses due to not meeting the qualifications of being a general or special educator in an elementary school (i.e., one participant reported teaching $10_{\text {th }}$ grade and two participants identified as specialists rather than teachers). Therefore, the final sample size was 173 participants: 116 general educators and 57 special educators. Teachers were asked to complete a demographic questionnaire. Overall, 93.6\% were female, $98.8 \%$ were White, and 96.5\% were not Hispanic or Latino. The median income level 
ranged from $\$ 75,000-\$ 99,999$, and the age of participants ranged from 22 years to 64 years. Additional descriptive statistics are reported in Table 1 to provide more information about the sample.

Participants were recruited in two stages. First, site permission was obtained from district administrators and/or building principals in order to contact teachers. Second, teachers were recruited via a school-wide email (written by us) sent by principals. Additional participants were recruited from an ISU College of Education listserv. Permission was granted from the ISU Coordinator of Graduate Programs in the College of Teaching and Learning, and then participants were invited via a listserv of teachers who returned to ISU to further their education. Lastly, participants were obtained via social media. A social media post was created, inviting teachers to participate in the study.

\section{Measures}

\section{Teacher Self Efficacy Scale (TSES)}

The Teacher Self Efficacy scale, sometimes referred to as the Ohio State Teacher Efficacy Scale, was developed by Tschannen-Moran and Hoy (2001). It is available to the general public and consists of 24 nine-point Likert-type responses ranging from 1- none at all to 9- a great deal. It is comprised of three subscales with the following reliabilities: Efficacy in Student Engagement $(\alpha=.87)$, Efficacy in Instructional Practices $(\alpha=.91)$, and Efficacy in Classroom Management ( $\alpha=.90$ ) (Tschannen-Moran \& Hoy, 2001). With regard to validity,

Heneman, Kimball, and Milanowski (2006) concluded that this scale is "the preferred measure of teachers' sense of efficacy" given its "replicable psychometric properties, behavioral richness in capturing the teacher role, and predictive capacity for explaining significant variance in teacher classroom performance" (p. 13). This scale was used to assess both special and general 
educators' efficacy in teaching students more generally, as this scale includes questions about students in general. In addition to the subscale scores, a composite general efficacy score was created by averaging all 24 item scores to assess overall teacher efficacy. The internal consistencies for my sample were as follows: Composite Efficacy $(\alpha=.94)$, Efficacy in Instructional Practices $(\alpha=.75)$, and Efficacy in Classroom Management $(\alpha=.80)$, demonstrating adequate reliability.

\section{Teaching Students with Disabilities Efficacy Scale (TSDES)}

The Teaching Students with Disabilities Efficacy Scale (TSDES) was developed by Dawson and Scott (2013) to assess teacher (pre-service and in-service) self-efficacy for teaching students with disabilities. The framework of the TSDES was built upon an existing instrument, the TSES, and uses a 9-point Likert rating scale for consistency (1- certain I cannot do to 9certain I can do). The scale is comprised of 19 questions and five subscales that define efficacy and have demonstrated statistical reliability: Instruction $(\alpha=.88)$, Teacher Professionalism $(\alpha=$ .84), Teacher Support $(\alpha=.85)$, Classroom or Behavior Management $(\alpha=.88)$, and Related Duties $(\alpha=.78)$ (Dawson \& Scott, 2013). Additionally, the correlation between the TSES and TSDES was examined in previous literature in order to determine the validity of the TSDES. The two scales were positively correlated, demonstrating that the two scales are similar, but measure separate constructs $(\mathrm{r}=.742, \mathrm{p}=.000$; Dawson $\&$ Scott, 2013). This confirms that teacher efficacy for teaching students with disabilities is a distinct construct, warranting the use of a separate efficacy scale. In addition to the subscale scores, a composite score, averaging all 19 item scores, was created to assess teacher efficacy for teaching students with disabilities. The internal consistencies for my sample were as follows: Composite Efficacy $(\alpha=.87)$, Instruction 
$(\alpha=.91)$, Teacher Professionalism $(\alpha=.87)$, Teacher Support $(\alpha=.91)$, Classroom

Management $(\alpha=.82)$, and Related Duties $(\alpha=.83)$, demonstrating adequate reliability.

\section{Experience Related to Teaching Students with Disabilities}

Teachers were asked to answer questions specific to working with students with disabilities. First, teachers were asked answer questions related to experience; for example, how many students with an IEP they have taught in the past three years and how many years of hands-on experience have they had working with students with disabilities. For those who selected more than zero years of experience, they were asked to explain their current level of experience (i.e., practicum, summer camp/babysitting, family member). Second, teachers were asked to describe their educational experience, including the number of college courses they have taken related to special education, inclusion, and/or students with disabilities. Third, teachers were asked to answer questions related to professional development specific to inclusion and students with disabilities, including professional development received, and professional development topics that would be beneficial to their success as a teacher. Fourth, teachers were asked to respond to questions related to collaboration: with whom they collaborate (i.e., school psychologist, special educators, general educators, paraprofessionals, principals, parents, social workers, specialists, and special education director or other administrators) and how often (ranging from $1=n e v e r$ to $5=v e r y$ frequently). Additionally, teachers were given the 13 disability categories recognized by IDEA and they were asked to 1) select the disabilities with which they have direct experience and 2) rate how comfortable they feel working with students with the various disabilities ( 1 =very uncomfortable to 5=very comfortable). Lastly, the survey included questions related to difficult experiences working with a student with a disability and a time the teachers felt very efficacious, and an open-ended response section to acquire general perceptions 
and other information not explicitly queried. Data were used to provide context for the efficacy scores and as exploratory analyses with the goal of providing information leading to an eventual dissertation.

\section{Procedure}

Approval was obtained from the Illinois State University Institutional Review Board (IRB-2019-242), and the study was determined to be exempt. To obtain participants, site permission was obtained from district administrators and/or building principals. Specific schools were randomly selected by an examination of schools across the state and in different counties. Once approval was obtained, participants were recruited via a school-wide email. The ISU Associate Director and Coordinator of the Graduate Programs in the School of Teaching and Learning was also contacted, and once approval was obtained, a similar email was sent out via a listserv. The individuals on this listserv were in-service teachers who returned to the university to

further their education. Lastly, participants were obtained through social media. The emails and social media posts included a brief description of the current study and contained a link to the online study. All scales were administered via Qualtrics, an online, secure software.

Compensation was introduced after obtaining 19 responses, in order to increase response rates. Upon completion of the survey, the remaining participants were eligible for a chance to receive one of four \$15 electronic Amazon gift cards. Email addresses were obtained but were not linked to the survey details and were destroyed upon receipt of gift card. 


\section{CHAPTER IV: RESULTS}

\section{Analysis}

Data from the surveys were analyzed using the Statistical Package for the Social Sciences (SPSS) software, version 26.0.

\section{Research Question 1}

Research Question 1 assessed whether general educators were less efficacious in teaching students with disabilities, in comparison to special educators. The question was analyzed using an independent samples $t$ test, comparing subscale and composite scores on the TSDES for general and special educators. I hypothesized that special educators would demonstrate higher levels of teacher-efficacy in teaching students with disabilities for both the subscale and composite scores, in comparison to general educators. The results supported my hypothesis in that there was a statically significant difference between general and special educators for the Overall Composite, $t(171)=-3.73, p=.000$, and the following subscales: Instruction, $t(171)=$ -2.79, $p=.006$, Classroom Management, $t(171)=-2.35, p=.020$, and Related Duties, $t(171)=$ $-4.62, p=.000$. There was no statistically significant difference between general and special educators for the Professionalism subscale, $t(171)=.31, p=.755$, and Teacher Support subscale, $t(171)=-.40, p=.688$. In conclusion, on the efficacy scale assessing efficacy for working with students with disabilities, special educators, overall, reported higher levels of efficacy in comparison to general educators. In regard to the five subscales, special educators reported higher efficacy scores than general educators on all scales except for the Professionalism and Teacher Support subscales. See Table 2 for more information. 


\section{Research Question 2}

Research Question 2 assessed how efficacy differed for general educators, comparing efficacy for teaching students with disabilities and teaching students in general. Thus, the question was analyzed by comparing standardized composite scores on both the TSES and TSDES for general educators via a paired samples $t$ test. Standardized scores for similar subscales from the two efficacy measures (i.e., Instruction and Classroom Management) were analyzed via paired samples $t$ tests as exploratory analyses meant to provide details about the locus of expected differences. I hypothesized that general educators would be more efficacious in teaching students in general, for both the composite and subscale scores, in comparison to teaching students with disabilities. The results indicate that general educators reported significantly higher efficacy composite scores on the TSES in comparison to the TSDES, $t(115)$ $=2.35, p=.020$, indicating higher levels of efficacy in teaching students in general than with teaching students with disabilities. General educators did not report a statistically significant difference between the TSES and TSDES for the Instruction subscale, $t(115)=1.31, p=.194$, or for the Management subscale, $t(115)=1.06, p=.291$, indicating no differences in efficacy related to instruction or classroom management for students in general and students with disabilities. These results indicate that general educators reported higher levels of (standardized composite) efficacy for teaching students in general than for teaching students with disabilities; however, the findings comparing the two similar subscales did not reveal any statistically significant results. Together, these findings provide some support for my initial hypothesis. See Table 3 for more information about the scores. I present raw subscale and composite scores (rather than standardized scores) for ease of interpretation. 


\section{Research Question 3}

The final research question assessed the factors that might be related to teacher efficacy, and the results were analyzed quantitatively and qualitatively, with the goal of providing context and foreshadowing an eventual dissertation. I probed aspects of education, experience, and support that may be related to teacher efficacy with regard to students with disabilities for general and special education teachers in public elementary schools. Qualitative details were coded using grounded theory (Strauss \& Corbin, 1998) by reading each response, outlining main ideas, and then organizing the main ideas based on common themes that emerged across participant responses. Participants often provided a response spanning more than one category and thus the response codes are not mutually exclusive (i.e., many percentages add up to over $100 \%)$.

Education. Regarding education, $62 \%$ of participants had a master's degree, while 33\% had a bachelor's degree. Approximately $28 \%$ of the sample reported receiving a degree from Illinois State University. While college majors differ by school, a majority of participants received a degree in elementary education (53\%) or special education (28\%). Teachers were also asked to describe their educational experience, including the number of college courses they had taken related to special education, inclusion, and/or students with disabilities. In the overall sample, $4 \%$ of participants reported 0 courses and $43 \%$ reported 5 or more courses. When comparing general and special educators, general educators reported a median score of 3 which equates to 2 courses, while special educators reported a median score of 6 which equates to 5+ classes. $90 \%$ of special educators took $5+$ courses, compared to $19 \%$ for general educators. See Table 4 for more information. 
Next, teachers were asked to provide responses in an open-ended format for two questions related to professional development. Responses were coded qualitatively, with some responses spanning two or more categories. Participants reported numerous professional development topics that they have received, including: minimal to no professional development (31\%; e.g., the question was not applicable, occasional professional development, and the expression of need for more training), inclusion practices (18\%; e.g., co-teaching, differentiation/accommodation, collaboration, and writing an IEP), Crisis Prevention and Intervention Training (CPI; 10\%), social-emotional and behavioral needs (9\%), ASD (8\%), Reading/Dyslexia (6\%), ADHD (5\%), trauma/Adverse Childhood Experiences (ACEs; 3\%), and disability law (2\%). Additionally, 28\% reported receiving professional development, but did not specify the topic, and 5\% reported other topics that did not fit into any particular category.

Teachers were also asked to report professional development topics that would be beneficial to their success as a teacher. The following topics were reported: Inclusion (25\%; e.g., co-teaching, differentiation/modification/accommodation, and understanding and writing an IEP) ASD (15\%), Behavior Management (14\%; e.g., discipline, classroom management, and handling temper tantrums), ADHD (12\%), trauma (10\%), social-emotional learning (10\%; e.g., depression, anxiety, emotion problems, and emotional disturbance), Deaf/Blindness (3\%), technology (2\%), special education law (2\%), and motivating students (2\%). Additionally, $9 \%$ reported wanting general training in this area, and $12 \%$ reported other topics. See Table 4 for more information.

Experience. Overall, the sample reported teaching 2-80 students with an IEP in the past three years. A majority of the sample (58.4\%) reported 10+ years of hands-on experience working with students with disabilities. The teachers in the sample reported numerous types of 
experiences in an open-ended response style. Responses were coded qualitatively, with some responses spanning two or more categories. Teachers noted experiences they have had over the course of their teaching (90\%), having a family member with a disability (13\%), working at a summer camp or babysitting (10\%), practicum experiences (10\%), and other (4\%). See Table 5 for more information.

Teachers were also asked to describe their experience and comfort level with the 13 IDEA disability categories. The overall sample described a substantial amount of experience with ASD (87\%), Other Health Impairment (87\%), Speech or Language Impairment (83\%). Specific Learning Disability (81\%), Emotional Disturbance (73\%), and Intellectual Disability (71\%). Limited experience was reported for low-incidence disabilities such as Deaf-Blindness $(5 \%)$ and Deafness (9\%). In order to compare experience by teacher type, a Chi-square analysis was conducted. Overall, statistically significant differences were found for the following categories: ASD: $\chi 2(1)=6.494, p=.011$; Emotional Disturbance: $\chi 2(1)=5.080, p=.024$; Intellectual Disability: $\chi 2(1)=7.113, p=.008$; Multiple Disabilities: $\chi 2(1)=4.649, p=.031$; Other Health Impairment: $\chi 2(1)=4.757, p=.029$; Specific Learning Disability: $\chi 2(1)=5.846, p$ $=.016$; and Traumatic Brain Injury: $\chi 2(1)=4.075, p=.044$. A higher percentage of special educators reported experience in all of the 7 categories listed above. The six categories that were insignificant by teacher type, were Deaf/Blind: $\chi 2(1)=.568, p=.451$; Deafness: $\chi 2(1)=.001, p$ $=.973$; Hearing Impairment: $\chi 2(1)=.955, p=.328$; Orthopedic Impairment: $\chi 2(1)=.037, p=$ .847; Speech or Language Impairment: $\chi 2(1)=2.226, p=.136$; and Visual Impairment: $\chi 2(1)=$ $.004, p=.949$. See Table 5 for more information regarding percentages and the Chi-square analyses $(* p<.05)$. 
Regarding comfort level with the IDEA disability categories, participants' responses were skewed towards the uncomfortable end of the scale for the following categories: DeafBlindness, Deafness, and Visual Impairment, coinciding with reports of experience. See Table 5 for percentages based on the Likert scale ( 1 =very uncomfortable to $5=$ very comfortable $)$. Additionally, an independent samples $t$ test was conducted to examine differences in levels of comfort by teacher type. See Table 6 for the mean comfort levels by disability category and teacher type. There was a statistically significant difference between general and special educators on the following disability categories: $\operatorname{ASD}[t(168)=-4.79, p=.000]$, Emotional Disturbance $[t(168)=-5.86, p=.000]$, Multiple Disabilities $[t(167)=-3.75, p=.000]$, Intellectual Disability $[t(169)=-4.67, p=.000]$, Specific Learning Disability $[t(169)=-4.67$, $p=.000]$, Other Health Impairment $[t(168)=-3.86, p=.000]$, and Traumatic Brain Injury $[t$ $(169)=-6.04, p=.000]$. Overall, special educators reported higher levels of comfort across all seven of these categories. No significant differences were found for the other six categories: Deaf-Blindness $[t(167)=-.81, p=.418]$, Deafness $[t(167)=-.37, p=.714]$, Visual Impairment $[t(168)=-1.79, p=.076]$, Hearing Impairment $[t(168)=1.00, p=.320]$, Orthopedic Impairment $[t(168)=-1.35, p=.179]$, and Speech or Language Impairment $[t(166)=-.15, p=$ $.885]$.

Support. As for support, $50 \%$ of participants reported collaborating very frequently with other regarding the needs of students with disabilities (General Educator $=40 \%$, Special Educator $=70 \%$ ). Additionally, $75 \%$ of the sample reported collaborating with school psychologists $($ General Educator $=69 \%$, Special Educator $=86 \%)$ and $80 \%$ reported collaborating with parents. See Table 7 for percentages regarding both frequency of collaboration and type of collaborator. Additionally, an independent samples $t$ test was 
conducted to examine differences in frequency of collaboration by teacher type. The results of this analysis can be found in Table 8. Although both types of educators reported high mean levels of collaboration, there was a statistically significant difference between general and special educators $[t(167)=-3.869, p=.000]$, with special educators collaborating more frequently.

Open Ended Probes. Additionally, the open ended probes were used to provide additional context surrounding teacher efficacy for teaching students with disabilities, which may be helpful with regard to future areas of research focus. All probes were analyzed qualitatively, by thoroughly reading through each response and organizing the responses into common categories.

First, teachers were asked to describe a difficult time they experienced when working with a student with a disability. The following experiences were reported: difficulties surrounding maladaptive behaviors (53\%; e.g., aggression, Emotional Disturbance, outbursts, and acts of defiance), academic concerns (14\%; e.g., concerns regarding academic performance and the modification and differentiation of curriculum), lack of support (14\%; e.g., lack of support from administrators, lack of training and professional development, large class sizes, and lack of aides), difficulties with parents (11\%; e.g., lack of parental support or disagreements between school and home), attention/engagement/motivation (5\%; e.g., difficulties keeping students attentive, engaged, and motivated in school), technology (3\%; e.g., lack of technology or limitations associated with its use), and other (13\%).

Second, teachers were asked to describe a time in which they felt very confident working with a student with a disability. The following experiences were reported: students achieving academic success (35\%; e.g., academic growth, meeting students at their level, and knowing the 
supports necessary to achieve academic success), support (19\%; e.g., support from parents/staff and receiving the necessary training), social-emotional success (9\%; e.g., students' increase in emotional-regulation and social interaction, and being able to assist when children are upset), behavioral supports (8\%; e.g., students' decrease in tantrums and increase in attention through the use of behavioral supports such as break cards and visuals), success due to experience (3\%; e.g., personal experiences and connection with the students), general success (10\%; e.g., numerous experiences leading to success, but specifics were not mentioned), and other (12\%).

Lastly, teachers were asked to provide any other comments, questions, or concerns that were not explicitly queried. In total, 53 responses were provided; however, only 24 responses were deemed valid, as many participants wrote "no comment or not applicable." Of the 24 responses, 33\% reported needing more professional development, training, and special education classes. Additionally, 25\% reported their admiration for teaching and working with students with disabilities. The other $42 \%$ reported multiple concerns regarding 1) the need for social-emotional learning in low income schools, 2) students no longer qualifying for services as they transition from early childhood education to kindergarten, 3) the downfalls of state testing, 4) difficulties with adapting curriculum, 5) students with severe behavioral concerns, 6) students having to demonstrate failure before qualifying for special education services, and 7) not having enough staff to best meet the needs of students with disabilities. See Table 9 for percentages regarding all open ended responses. 


\section{CHAPTER V: DISCUSSION}

Teacher efficacy is defined as a teacher's belief in his or her ability to effectively teach and promote student engagement and learning (Tschannen-Moran \& Hoy, 2001). With the rise of inclusive education and the blurring of general and special education, the primary goal of this study was to analyze teacher efficacy in multiple domains. First, I examined the differences between general and special educators in their efficacy for teaching students with disabilities. Despite research describing general educators who do not feel confident in their abilities to effectively teach students with disabilities in the general education classroom (Blanton, L. P., Pugach, M. C., \& Florian, L., 2011; Buell et. al, 1999; Hussien and Qaryouti, 2015; Polou, 2005; Rosenzweig, 2009), teachers in my sample reported relatively high efficacy related to teaching students with disabilities. However, general educators reported lower efficacy related to students with disabilities than did special educators, as predicted. General educators also reported significantly lower levels of efficacy for the following subscales: instruction, classroom management, and related duties, indicating that in comparison to special educators, general educators feel less confident in their ability to adapt curriculum, deal with disruptive behaviors, and assist students with transportation, medication, and feeding. This finding is consistent with prior research on general educators, stating that general educators often do not receive extensive training on differentiating instruction and understanding and implementing an IEP (Rosenzweig, 2009). Special educators, on the other hand, possess specialized knowledge in the education of students with disabilities, as they receive more training on inclusion-related knowledge (e.g., IEPs, disability law, and behavior management) than general educators (Gehrke \& Cocchiarella, 2013; Oliver \& Reschly, 2010). These areas of differences in training may be problematic given that under IDEA, more and more students with an IEP are taught in the general education setting. 
General educators are expected to be knowledgeable and compliant with disability law and accommodate students with various needs without receiving the same amount of training, experience, and support as special educators; thus, contributing to differences in efficacy between general and special educators.

Second, I assessed how efficacy differed for general educators, comparing efficacy for teaching students with disabilities and teaching students in general. I found that general educators reported significantly higher overall efficacy scores in teaching students in general compared to teaching students with disabilities when analyzing standardized scores; however, the findings comparing the two similar subscales did not reveal any statistically significant results. Thus, these findings provide some support for my initial hypothesis. It is possible that the lack of findings for the two subscales are related to methodological issues. Although both efficacy scales are psychometrically sound, the scales were written with differing levels of specificity. The Teaching Students with Disabilities Efficacy Scale (TSDES; Dawson \& Scott, 2013) is comprised of items that include construct-related tasks written in very specific and concrete language. The Teachers Sense of Efficacy Scale (TSES; Tschannen-Moran \& Hoy, 2001), in contrast, is written with slightly less specificity. It is possible that the manner in which the questions were framed influenced participants' ability to answer the question to the best of their ability. The TSDES uses the language "I can..." while the TSES uses the language "how much...?" The methodological variance associated with these two scales should be investigated if researchers are interested in using these two scales in a comparison format such as the manner used in the current study.

Lastly, based on prior research (deBettencourt, 1999; Lohrman \& Bambara, 2006; Rosenzweig, 2009), I assessed three factors that may be related to teacher efficacy: education, 
experience, and support. Overall, special educators reported higher levels of inclusion-related education, experience, and support than general educators. Special educators reported taking more college courses related to students with disabilities and/or inclusion practices, reported more experience and higher levels of comfort with a majority of the 13 IDEA categories, and reported collaborating more often with others regarding the needs of students with disabilities.

Regarding the IDEA categories, my results demonstrate that comfort level increases along with experience. Limited experience was reported for low-incidence disabilities such as Deaf-Blindness and Deafness, and the resulting average comfort level was much lower than that of higher-incidence disabilities. On the other hand, Other Health Impairment, for example, was reported as the second highest category with the most experience and it received the highest average comfort score. Additionally, Autism was reported as the disability with which teachers in this sample had the most experience. The corresponding comfort score was reported to be in the comfortable range. Therefore, consistent with prior research (Able et. al, 2015; Bray-Clark \& Bates, 2003; Burke \& Sutherland, 2004; Leyser et. al, 2011;), the more experience teachers have with various disabilities, including pre-service and in-service training, the more comfortable they feel working with individuals who have those disabilities. Experience working with students with disabilities provides teachers with the opportunity to actively apply teaching strategies discussed in the classroom, learning the strengths and weaknesses to their approach (Burke \& Sutherland, 2004). This experience may, in turn, increase teacher efficacy and promote positive attitudes toward inclusion (Frankel, Hutchinson, Burbidge, \& Minnes, 2014; Leatherman \& Niemeyer, 2005).

Qualitative analyses demonstrated common themes across all teacher participants, including 1) a lack of training and support (e.g., professional development, coursework, and 
support from school staff) and 2) concerns regarding behavior management. Across all participants, only $18 \%$ of the sample reported receiving some sort of professional development related to students with disabilities and inclusion. On the same question, $31 \%$ reported minimal to no professional development in this area. When asked about topics that would be beneficial to their success as teachers, $25 \%$ of the sample reported that they would benefit from additional professional development on inclusion practices. Furthermore, on the final question allowing teachers to comment about anything not specifically queried, 33\% reported for a second time that they need more professional development, training, and special education classes. Thus, consistent with prior research, educators are not receiving enough pre-service and in-service training related to educating students with disabilities in the inclusive setting (Allday, NeilsenGatti, \& Hudson, 2013; Fuchs, 2010).

Support was another area of concern reported by teachers in this sample and evidenced in prior research (Fuchs, 2010). 14\% of my sample described lack of support when asked about a difficult time they experienced when working with a student with a disability. Specific concerns included lack of support from administrators, lack of training and professional development, large class sizes, and lack of aides. Research indicates that supports such as a lower student-toteacher ratio and higher availability of aides/paraprofessionals are pertinent to teaching success. When these supports are diminished, teachers can feel overwhelmed and less efficacious in their ability to meet the individual needs of each of their students while also teaching the class as a whole (Bunch, Lupart, \& Brown, 1997; Lohrman \& Bambara, 2006). Additionally, 11\% reported specific difficulties related to parents, including lack of parental support and disagreements between home and school. Home-school communication and collaboration is an important aspect of teaching, as a quality intervention should fit the needs of the child in both the home and 
school setting (Fettig, Schultz, \& Ostrosky, 2013). When asked to describe a time they felt confident working with students with disabilities, $19 \%$ of the sample reported success related to feeling supported from parents and staff and receiving the necessary training. Thus, in line with previous research (Lohrman \& Bambara, 2006), when the necessary support is provided, teacher efficacy increases, signaling the need for schools and administrations to look carefully at the current supports they have in place and consider ways in which they can be improved.

Additionally, special educators reported collaborating with others more often regarding the needs of students with disabilities than general educators. Specifically, special educators reported collaborating more often with school psychologists, directors of special education/administrators, parents, specialists, paraprofessionals, and social workers, to name a few. Collaboration is an extremely important aspect of teaching in which efficacy can be fostered. Differences between general and special educators should diminish as collaboration is emphasized as an integral aspect of school climate.

The second area of concern evident from teachers in my study is in the area of behavior management. When teachers were asked to describe a difficult experience they have had with students with disabilities, 53\% reported difficulties surrounding maladaptive behaviors. As previously discussed, many teachers view children who exhibit problem behaviors as more challenging to work with, leading to teachers feeling overwhelmed (Alverez, 2007). Experience and training related to behavior management has been shown to increase teacher efficacy and provide educators with a sense of confidence that their students' behavioral needs are not beyond their ability (Lohrman \& Bambara, 2006). However, only 9\% of the sample reported receiving professional development related to social-emotional and behavioral needs. $10 \%$ reported receiving Crisis Prevention and Intervention Training, a behavioral de-escalation training, but 
one respondent reported that "despite [their] training as an associate/trainer with Crisis Prevention Institute, [they] feel like [they] need a higher level of training on how to properly work productively with these students." In fact, $14 \%$ of participants reported wanting more training on behavior management. Therefore, the results of this study demonstrate that educators are in need of more training in the area of behavior management, especially as behaviors become increasingly aggressive and violent.

\section{Implications for Practice}

The implications of this study for educators, school psychologists, and administrators are numerous. Educators are tasked with the very challenging job of helping students achieve academic and social-emotional success, regardless of ability or disability status. However, as demonstrated in this study, there are numerous barriers in place that are limiting educators from feeling efficacious and, in turn, possibly impacting the success of their students. Based on the findings from this study, three target areas have been identified: pre-service training, in-service training, and collaboration with others.

First, pre-service training is important to the success of an educator, as it is the first professional training received by those wishing to enter the teaching profession. Educator needs to have all of the tools in their toolbelt in order to effectively teach. Student achievement depends on the quality of teachers, and since teacher preparation programs provide educators with the basic tools in their toolkit, student success depends on the quality of pre-service

programs (United States Agency for International Development, 2011). Without the proper tools, children end up falling through the cracks of the system. To combat this, teachers' pre-service needs should be acknowledged. Teacher preparation programs, particularly those teaching general educators, need to consider increasing the number of courses related to special 
education/inclusion and behavior management, and/or infusing these themes across all courses and experiences. We acknowledge that pre-service program coordinators carefully select classes and create coursework requirements. It is an impossible feat to continue to add courses while also maintaining the rigor of the other requirements that add to the well-rounded training of general educators. Additionally, we acknowledge that general and special educator training differ because of the populations they serve. However, with IDEA (2004) and the influx of special education students into the general education setting, general educators are in need of more training that is typically reserved for special educators. This training can be implemented in a variety of ways, including the addition of courses, the infusion of material, and/or by adopting a different model of training. Program restructuring is done on a large-scale basis and involves reevaluating all program requirements to meet a common set of standards for all educators. Program enhancement, in contrast, is more flexible and allows the addition of courses, adjustment of courses, and integration of practicum experiences (Gao \& Mager, 2011; Peterson \& Beloin, 1998). Voltz (2003) outlined the success of collaborative infusion, in which special education content is infused in teacher preparation programs, rather than enhancing or adding single courses (Gao \& Mager, 2011; Voltz, 2003). In line with recommendations from Leyser, Zeiger, and Romi (2011), a single course on inclusion is insufficient in increasing teacher efficacy. In fact, diversity in learning should be emphasized and discussed across all courses (Gao \& Mager, 2011). Specific inclusion topics discussed in the current study include coteaching, differentiation, and understanding and writing an IEP. Pre-service teachers should also be given the opportunity to directly observe and practice the skills being taught in the classroom, through pre-practicum, practicum, and internship experiences. Behavior management is also an important area that deserves its own concentrated focus. According to the National Council on 
Teacher Quality's (2014) analysis of 122 teacher preparation programs, behavior management is often scattered throughout training in a disconnected and unconcentrated manner. Furthermore, the researchers found that most programs do not teach research-based behavior management strategies. Specific behavior management strategies to teach include how to "establish and teach rules, build structure and routine into the classroom, use praise to reinforce positive behavior, address misbehavior, and maintain student engagement" (National Council on Teacher Quality, 2014). Thus, teacher preparation programs should consider either mandating a course on behavior management or infusing behavior management principles across all coursework. The training should focus on research-based strategies and provide the opportunity to directly practice the principles being taught in the classroom. Researchers recommend that students, during field-based experiences, be required to pay close attention to the management style in their classroom, including rules, procedures, and routines (Shamina \& Mumthas, 2018). Students should also be provided with the opportunity to implement behavior management strategies with guided practice and immediate feedback (Shamina \& Mumthas, 2018). Furthermore, the Illinois State Board of Education recently provided new guidance on time outs, isolated time outs, and the use of physical restraint (2020). As the laws on this topic change, it is important for preservice programs to be up to date with the current laws and practices in order to provide the most current information to teachers.

Second, in-service training is a particularly important area to target for general and special education teachers. The process of learning does not stop upon the conferral of a degree. In fact, learning is a lifelong process. Professional development is an avenue in which educators can gain and improve knowledge and skills related to their teaching. According to the National Education Association, teachers should have a voice in the training they receive (National 
Education Association, n.d.). The results of the current study indicate that teachers are requesting trainings focused on inclusion related practices, Autism Spectrum Disorders, and behavior management. Schools and administrations should carefully consider the specific needs of their schools as well as probe educators regarding their needs, prior to determining the years' professional development topics (Burrowes, 2016). School districts should also be supportive of educators who wish to privately seek out professional development. Educators often work well beyond the bell schedule, making it difficult for them to find time to complete extra hours of work related to professional development. Private professional development can also be costly. School districts should be cognizant of these barriers, and to the best of their ability, allocate the necessary funds and resources to allow for professional development (e.g., provide reimbursement and approved time-off) (National Comprehensive Center for Teacher Quality, 2011).

Lastly, collaboration is a key component of an effective school team. In fact, IEP teams require collaboration across a wide variety of staff, including parents, general and special educators, principals, and specialists, to name a few. The emphasis on collaboration can differ by school, depending on whether school staff are integrated or isolated. An integrated team, for example, may all be housed within the school building. An isolated team, on the other hand, may be spread out with educators working in the school building and specialists working throughout the district and/or meeting the needs of multiple schools. This isolated scenario is common in rural areas of Illinois, as many specialists are hired by special education cooperatives who meet the needs of multiple school districts. Thus, physical distance and accessibility can be barriers to collaboration (Nichols, Goforth, Sacra, \& Ahlers, 2017). Regardless, it is important for schools to place more of an emphasis on collaboration, as much can be learned by meeting with 
individuals who have received different training and had different experiences (Able et al., 2015). Researchers also suggest a barrier to collaboration is teachers lacking training in effective collaboration and communication; thus, in-service training can also be conducted in this domain (Montgomery \& Mirenda, 2014). A school that promotes collaboration, in turn, creates a more supportive environment. When teachers feel supported, efficacy increases.

\section{Limitations and Future Directions}

\section{Sample}

One limitation of the current study was the lack of racial/ethnic diversity and lack of male representation in the sample of public school elementary teachers. According to the Illinois Report Card from 2018-2019, teachers in the state of IL, across all age groups (i.e., elementary school, middle school, and high school), were 83\% White and 77\% Female (Illinois Report Card, 2019). There is research to suggest that there are a lower percentage of male teachers at the elementary school level, approximately $11 \%$, compared to middle school and high school (National Center for Education Statistics, 2018). With the $11 \%$ difference in mind, we approximate that $88 \%$ of elementary school teachers in the state of Illinois identify as female. The participants in this study were 99\% White, 94\% Female, and 97\% not Hispanic or Latino. When comparing this sample to state averages, this study included $16 \%$ more participants who identified as White and 6\% more who identified as female. Thus, this study does not mirror all teachers in the state of IL and results must be interpreted in the context of a predominantly-white and female sample, limiting the generalizability of the results for teachers with different identities. Future studies should seek out a more generalizable sample. 


\section{Self-Report}

Another limitation to the current study was the utilization of measures of self-report. Although self-report is a convenient method to capture individual's thoughts, beliefs, and opinions, self-reports are not always accurate. In general, these measures lack direct observation (Baumeister, Vohs \& Funder, 2007). It is possible that participants rated their efficacy as higher than it would be if their behavior was observed by an unbiased observer, also known as the social desirability bias (Lavrakas, 2008). The current study did not include a measure of social desirability, which could have provided more information regarding the high efficacy scores reported in the analysis of research question one. Future studies should include a social desirability measure and analyze the association between social desirability ratings and teacher efficacy scores.

\section{Sampling Bias}

As discussed in the participants section, this study excluded 40 participants for not completing both the TSES and TSDES efficacy scales. It is possible that completion of the scales depended on level of efficacy. The 173 teachers who were included in the analyses may have expressed greater efficacy and more positive experiences than those who did not complete the scales. This sampling bias may have inflated overall levels of efficacy, impacting the validity of the results.

\section{Measures}

This study is limited by the measures it utilized. Although the Teacher Self Efficacy Scale (TSES; Tschannen-Moran \& Hoy, 2001) has been widely used and has strong psychometric properties, the Teaching Students with Disabilities Efficacy Scale (TSDES; Dawson \& Scott, 2013) was newly developed and has not yet acquired a large literature base. 
Thus, the TSDES required research and validation. The internal consistencies for my sample were as follows: Composite Efficacy $(\alpha=.87)$, Instruction $(\alpha=.91)$, Teacher Professionalism ( $\alpha$ $=.87)$, Teacher Support $(\alpha=.91)$, Classroom Management $(\alpha=.82)$, and Related Duties $(\alpha=$ .83), demonstrating adequate reliability. These details are important given the scant research published using this scale. Furthermore, we were skeptical about comparing results across the TSES and TSDES, despite the two scales being positively correlated and the TSDES being built upon the TSES (Dawson \& Scott, 2013). Future studies should continue to utilize the TSDES, providing additional details about reliability and validity. Researchers may also wish to examine different avenues to distinguish between general teaching efficacy and efficacy for teaching students with disabilities. It is possible that an entirely new scale could be developed to best assess efficacy in this domain.

\section{Predictive Modeling}

Another limitation to this study is that the areas assessed in research question three were not analyzed based on their predictive power, but rather were analyzed in an exploratory manner. Although it is important to analyze components of teacher education, experience, and support in relation to teaching students with disabilities, no analyses were conducted to see how these details predict efficacy. Future studies should attempt to develop a predictive model of efficacy for teaching students with disabilities. The findings from the current study offer some details that are of importance, including teacher type, general efficacy scores, coursework, training, and confidence and experience with the 13 IDEA categories. Other details not queried in this study may also be important indicators of teacher efficacy for teaching students with disabilities and may better assist in making changes within the training and experiences of pre-service and inservice teachers. 


\section{Conclusion}

Teacher efficacy, a teacher's belief in their ability to effectively teach and promote student engagement and learning, is an important construct that has been shown to affect a teacher's willingness to meet the needs of their students, their persistence in face of difficulties, and the likelihood of referring difficult students to special education (Tschannen-Moran \& Hoy, 2001). Thus, teacher efficacy has important implications for teachers and students and may be particularly important in supporting inclusive environments. In order to create a fully inclusive environment, educators need the training, support, and experience to feel efficacious in their abilities, and in turn, help their students learn alongside their peers, while demonstrating academic and socioemotional growth. The results of this study demonstrate that overall, teachers report relatively high efficacy in teaching students with disabilities. However, differences appear when comparing general and special educators, in that general educators report lower levels of inclusion-related efficacy than special educators. Additionally, general educators reported higher overall (standardized) efficacy scores in teaching students in general than teaching students with disabilities, but no significant findings were present for the two subscales. This finding deserves further investigation. Lastly, this study brought to light some areas where teachers could use additional support with regard to inclusion-related education, experience, and support. In order to close the gap between general and special educators, as well as promote continued learning and success for all students, educators need more pre-service and in-service training and experiences related to inclusion practices and behavior management. Additionally, schools need to promote a more supportive environment by emphasizing collaboration across all staff and by integrating home-school collaboration. Thus, education, experience, and support critically impact teacher 
efficacy and should continue to be examined and remediated in order to increase teacher efficacy for teaching students with disabilities. 


\section{CHAPTER VI: TABLES}

Table 1

Descriptive Information for Overall Sample

\begin{tabular}{lllll}
\hline Variable & $\%$ & Range & Mean & SD \\
\hline
\end{tabular}

Teacher Type

General Educators

67.1

Special Educators

32.9

Gender

Male

6.4

Female

93.6

Race

White

98.8

Black

1.2

Asian

.6

\section{Ethnicity}

Hispanic or Latino

1.8

Not Hispanic or Latino

96.5

Other

1.7

\section{Household Income}

Less than $\$ 25,000$

.7

$\$ 25,000-\$ 49,000$

19.2

$\$ 50,000-74,999$

17.4

$\$ 75,000-\$ 99,999$

17.4

(Table Continues) 
Table 1, Continued

\begin{tabular}{|c|c|c|c|c|}
\hline Variable & $\%$ & Range & Mean & SD \\
\hline$\$ 100,000-\$ 124,999$ & 20.3 & & & \\
\hline$\$ 125,000-\$ 149,999$ & 8.7 & & & \\
\hline$\$ 150,000$ or more & 16.3 & & & \\
\hline Age & & $22-64$ & 44.06 & 50.61 \\
\hline \multicolumn{5}{|l|}{ Grades Taught } \\
\hline Kindergarten & 20.2 & & & \\
\hline First Grade & 28.3 & & & \\
\hline Second Grade & 34.7 & & & \\
\hline Third Grade & 27.2 & & & \\
\hline Fourth Grade & 27.7 & & & \\
\hline Fifth Grade & 20.8 & & & \\
\hline Other & 20.2 & & & \\
\hline Years Teaching Current Grade Level & & $0-31$ & 8.80 & 7.09 \\
\hline Total Number of Years Teaching & & $1-35$ & 14.92 & 9.06 \\
\hline \multicolumn{5}{|l|}{ Time Period Used to Answer the Survey } \\
\hline The Most Recent 3 years & 50.0 & & & \\
\hline The Most Recent 5 years & 22.9 & & & \\
\hline The Most Recent 10 years & 15.1 & & & \\
\hline More than 10 Years & 11.4 & & & \\
\hline Other & 6 & & & \\
\hline
\end{tabular}

Note: $N=173$ 
Table 2

Teaching Students with Disabilities Efficacy Scale (TSDES) Scores by Teacher Type

\begin{tabular}{lcc}
\hline \multicolumn{1}{c}{ Variable } & General Educators & Special Educators \\
& Mean (SE) & Mean (SE) \\
\hline Composite Score & $7.52(.08)^{*}$ & $8.03(.10)^{*}$ \\
Instruction Subscale Score & $7.45(.11)^{*}$ & $7.98(.14)^{*}$ \\
Classroom Management Subscale Score & $7.66(.11)^{*}$ & $8.07(.11)^{*}$ \\
Professionalism Subscale Score & $8.54(.69)$ & $8.51(0.63)$ \\
Teacher Support Subscale Score & $8.65(.67)$ & $8.69(.67)$ \\
Related Duties Subscale Score & $4.69(2.46)^{*}$ & $6.54(2.51)^{*}$ \\
\hline
\end{tabular}

Note: $N=173:$ General Educator $(n=116)$, Special Educator $(n=116)$

$* p<.05$ 
Table 3

Comparison of Raw Efficacy Scores for General Educators

\begin{tabular}{lcc}
\hline \multicolumn{1}{c}{ Variable } & TSES & TSDES \\
& Mean (SE) & Mean (SE) \\
\hline Composite Scores & $7.33(.81)^{*}$ & $7.52(.85)^{*}$ \\
Instruction Subscale Scores & $7.44(.92)$ & $7.45(1.22)$ \\
Classroom Management Subscale Scores & $7.45(.90)$ & $7.66(1.19)$
\end{tabular}

Note: $N=116$. TSES $=$ Teacher Self Efficacy Scale; TSDES = Teaching Students with

Disabilities Efficacy Scale. The analyses described in the main text utilized standardized scores

for comparison purposes. I present raw scores here for ease of interpretation.

$* p<.05$ 
Table 4

Descriptive Information for Education Variables

\begin{tabular}{|c|c|c|c|}
\hline \multirow{2}{*}{ Variable } & $\%$ Overall & $\%$ General & $\%$ Special \\
\hline & Sample & Educators & Educators \\
\hline \multicolumn{4}{|l|}{ Degree } \\
\hline Bachelor of Arts/Science & 32.9 & 27.6 & 43.8 \\
\hline Master of Arts/Science & 62.4 & 69.8 & 47.4 \\
\hline Other & 4.7 & 2.6 & 8.8 \\
\hline \multicolumn{4}{|l|}{ Number of College Courses Related to } \\
\hline \multicolumn{4}{|l|}{ Disability and Inclusion } \\
\hline 0 courses & 3.5 & 5.3 & .0 \\
\hline 1 course & 17.5 & 25.4 & 1.8 \\
\hline 2 courses & 17.0 & 23.7 & 3.5 \\
\hline 3 courses & 11.1 & 15.8 & 1.7 \\
\hline 4 courses & 8.2 & 10.5 & 3.5 \\
\hline $5+$ courses & 42.7 & 19.3 & 89.5 \\
\hline \multicolumn{4}{|l|}{ Professional Development Received } \\
\hline Minimal to No Training & 30.9 & 39.0 & 12.2 \\
\hline Inclusion & 17.5 & 12.0 & 28.6 \\
\hline Crisis Prevention and Intervention & 10.1 & 3.0 & 24.5 \\
\hline Social-Emotional and Behavioral Needs & 8.7 & 3.0 & 20.4 \\
\hline Autism Spectrum Disorder & 8.1 & 6.0 & 12.2 \\
\hline Reading/Dyslexia & 6.1 & 6.0 & 6.1 \\
\hline
\end{tabular}


Table 4, Continued

\begin{tabular}{|c|c|c|c|}
\hline Variable & $\begin{array}{c}\% \text { Overall } \\
\text { Sample }\end{array}$ & $\begin{array}{l}\% \text { General } \\
\text { Educators }\end{array}$ & $\begin{array}{l}\% \text { Special } \\
\text { Educators }\end{array}$ \\
\hline Attention-Deficit/Hyperactivity Disorder & 5.4 & 4.0 & 8.2 \\
\hline Trauma & 3.4 & 3.0 & 4.1 \\
\hline Special Education Law & 2.0 & 2.0 & 2.0 \\
\hline General Training & 28.2 & 28.0 & 28.6 \\
\hline Other & 5.4 & 6.0 & 4.1 \\
\hline \multicolumn{4}{|l|}{ Beneficial Professional Development } \\
\hline \multicolumn{4}{|l|}{ Topics } \\
\hline Inclusion & 25.4 & 23.9 & 28.6 \\
\hline Autism Spectrum Disorder & 14.6 & 15.9 & 11.9 \\
\hline Behavior Management & 13.9 & 10.2 & 21.4 \\
\hline Attention-Deficit/Hyperactivity Disorder & 11.5 & 15.9 & 2.4 \\
\hline Trauma & 10.0 & 9.1 & 11.9 \\
\hline Social-Emotional Learning & 10.0 & 9.1 & 11.9 \\
\hline Deaf-Blindness & 3.1 & 4.5 & 0.0 \\
\hline Technology & 2.3 & 2.3 & 2.4 \\
\hline Special Education Law & 1.5 & 0.0 & 4.8 \\
\hline Motivation & 1.5 & 0.0 & 4.8 \\
\hline General Training & 9.2 & 11.4 & 4.8 \\
\hline Other & 11.5 & 9.1 & 16.7 \\
\hline
\end{tabular}


Table 5

Descriptive Information for Experience Variables

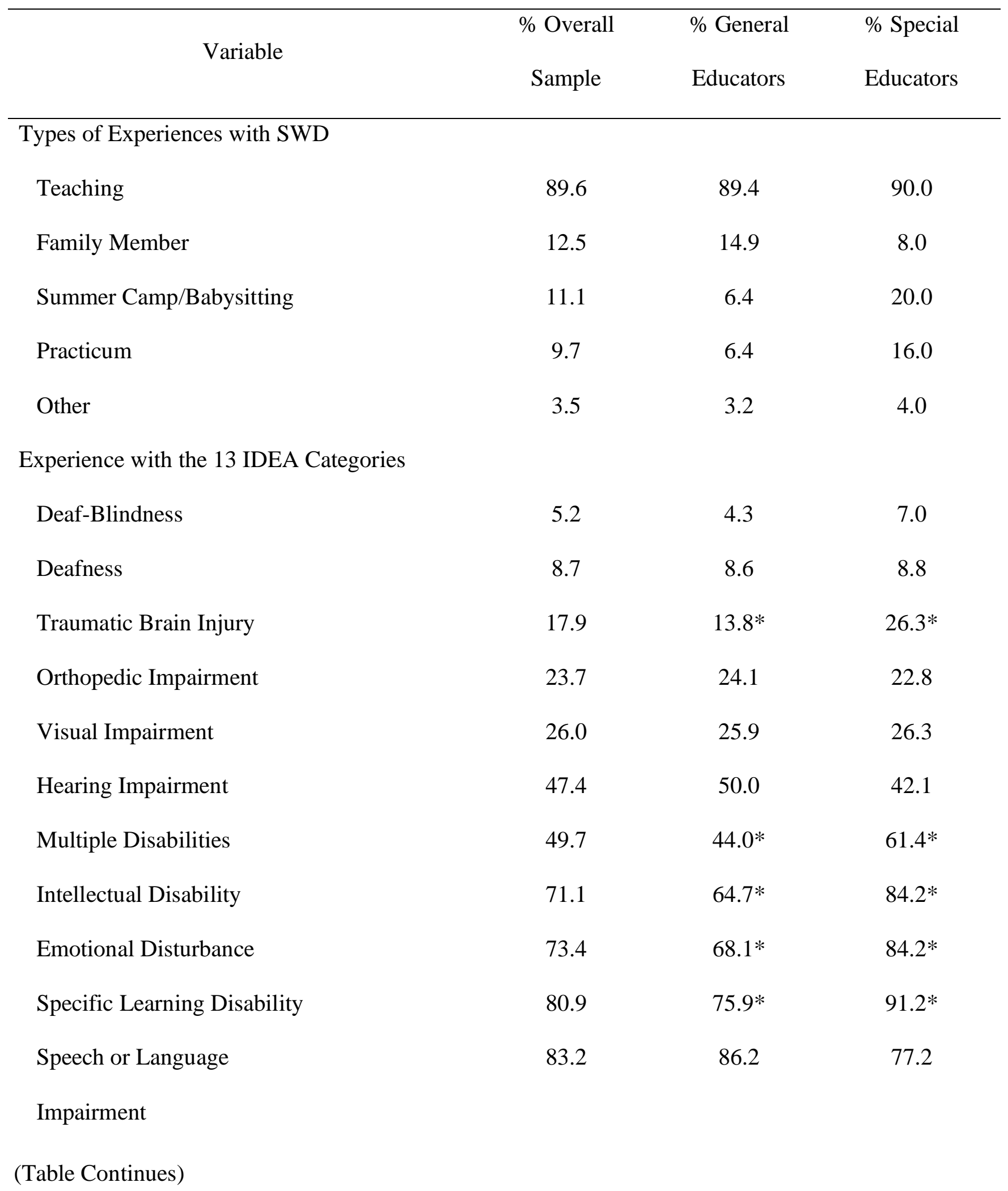


Table 5, Continued

\begin{tabular}{|c|c|c|c|}
\hline Variable & $\begin{array}{c}\% \text { Overall } \\
\text { Sample }\end{array}$ & $\begin{array}{l}\text { \% General } \\
\text { Educators }\end{array}$ & $\begin{array}{l}\% \text { Special } \\
\text { Educators }\end{array}$ \\
\hline Other Health Impairment & 86.7 & $82.8^{*}$ & $94.7^{*}$ \\
\hline Autism Spectrum Disorder & 87.3 & $82.8^{*}$ & $96.5^{*}$ \\
\hline \multicolumn{4}{|c|}{ Comfort Level with the 13 IDEA Categories } \\
\hline \multicolumn{4}{|l|}{ Autism Spectrum Disorder } \\
\hline Very Uncomfortable & 1.1 & 1.8 & .0 \\
\hline Uncomfortable & 2.4 & 3.5 & .0 \\
\hline Neutral & 16.5 & 18.4 & 12.5 \\
\hline Comfortable & 46.5 & 57.0 & 25.0 \\
\hline Very Comfortable & 33.5 & 19.3 & 62.5 \\
\hline \multicolumn{4}{|l|}{ Deaf-Blindness } \\
\hline Very Uncomfortable & 18.2 & 18. & 17.5 \\
\hline Uncomfortable & 24.3 & 28.6 & 15.8 \\
\hline Neutral & 38.5 & 32.1 & 50.9 \\
\hline Comfortable & 16.0 & 18.8 & 10.5 \\
\hline Very Comfortable & 3.0 & 1.8 & 5.3 \\
\hline \multicolumn{4}{|l|}{ Deafness } \\
\hline Very Uncomfortable & 11.8 & 11.5 & 12.5 \\
\hline Uncomfortable & 26.6 & 30.1 & 19.6 \\
\hline Neutral & 40.2 & 36.3 & 48.2 \\
\hline Comfortable & 17.8 & 18.6 & 16.1 \\
\hline
\end{tabular}


Table 5, Continued

\begin{tabular}{|c|c|c|c|}
\hline Variable & $\begin{array}{c}\% \text { Overall } \\
\text { Sample }\end{array}$ & $\begin{array}{l}\% \text { General } \\
\text { Educators }\end{array}$ & $\begin{array}{l}\% \text { Special } \\
\text { Educators }\end{array}$ \\
\hline Very Comfortable & 3.6 & 3.5 & 3.6 \\
\hline \multicolumn{4}{|l|}{ Emotional Disturbance } \\
\hline Very Uncomfortable & 2.9 & 4.4 & .0 \\
\hline Uncomfortable & 13.5 & 19.5 & 1.8 \\
\hline Neutral & 23.5 & 28.3 & 14.0 \\
\hline Comfortable & 38.8 & 36.3 & 43.9 \\
\hline Very Comfortable & 21.3 & 11.5 & 40.3 \\
\hline \multicolumn{4}{|l|}{ Hearing Impairment } \\
\hline Very Uncomfortable & 2.8 & 2.8 & 3.5 \\
\hline Uncomfortable & 7.1 & 8.8 & 3.5 \\
\hline Neutral & 30.6 & 26.5 & 38.6 \\
\hline Comfortable & 47.1 & 46.0 & 49.1 \\
\hline Very Comfortable & 12.4 & 15.9 & 5.3 \\
\hline \multicolumn{4}{|l|}{ Intellectual Disability } \\
\hline Very Uncomfortable & .6 & .9 & .0 \\
\hline Uncomfortable & 2.9 & 4.4 & .0 \\
\hline Neutral & 9.9 & 13.2 & 3.5 \\
\hline Comfortable & 43.9 & 50.9 & 29.8 \\
\hline Very Comfortable & 42.7 & 30.6 & 66.7 \\
\hline \multicolumn{4}{|l|}{ Multiple Disabilities } \\
\hline (Table Continues) & & & \\
\hline
\end{tabular}


Table 5, Continued

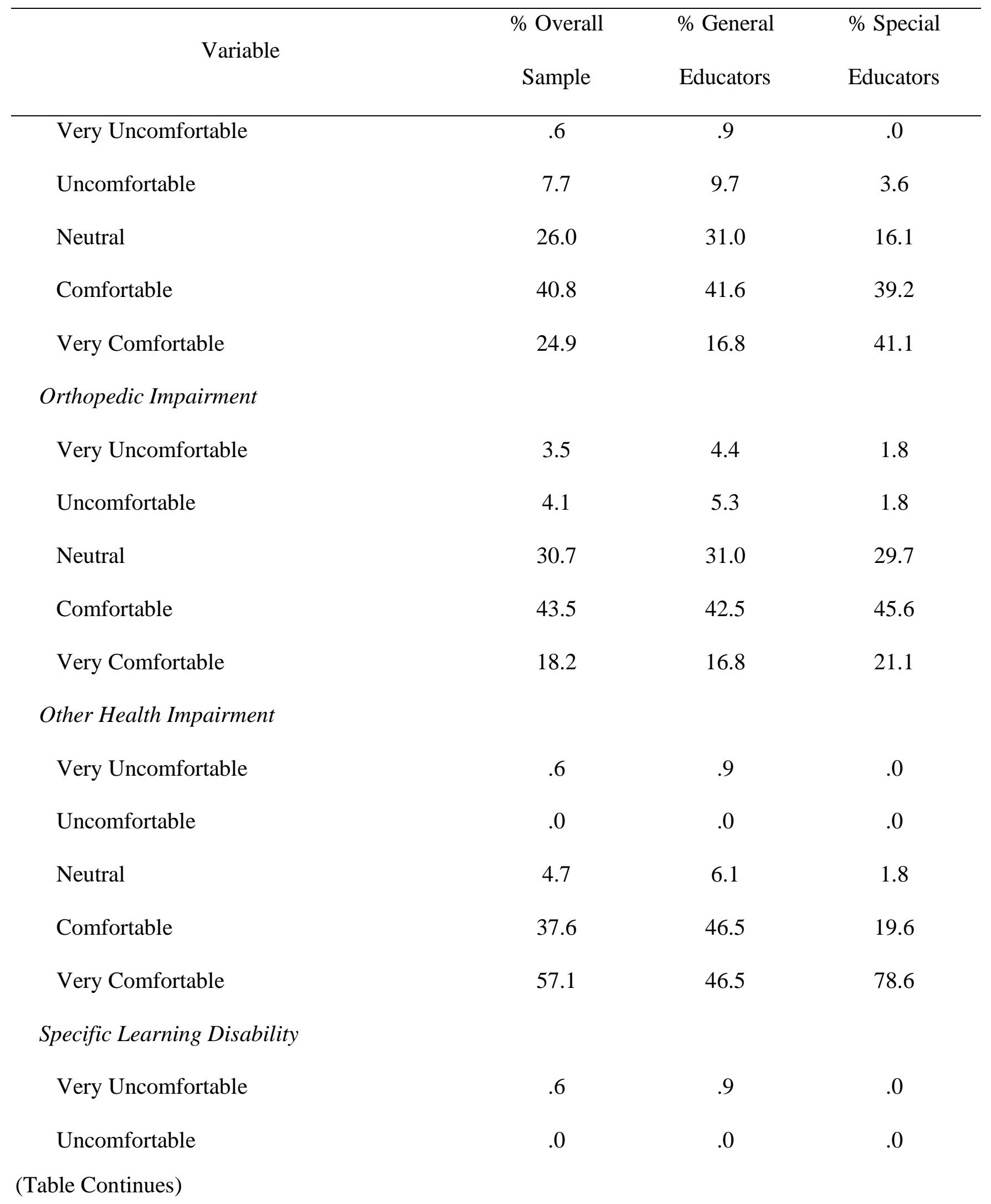


Table 5, Continued

\begin{tabular}{|c|c|c|c|}
\hline Variable & $\begin{array}{c}\% \text { Overall } \\
\text { Sample }\end{array}$ & $\begin{array}{l}\% \text { General } \\
\text { Educators }\end{array}$ & $\begin{array}{l}\text { \% Special } \\
\text { Educators }\end{array}$ \\
\hline Neutral & 5.8 & 8.8 & .0 \\
\hline Comfortable & 40.4 & 49.1 & 22.8 \\
\hline Very Comfortable & 53.2 & 41.2 & 77.2 \\
\hline \multicolumn{4}{|l|}{ Speech or Language } \\
\hline \multicolumn{4}{|l|}{ Impairment } \\
\hline Very Uncomfortable & 1.8 & .9 & 3.6 \\
\hline Uncomfortable & .0 & .0 & .0 \\
\hline Neutral & 4.8 & 3.6 & 7.1 \\
\hline Comfortable & 36.3 & 42.9 & 23.2 \\
\hline Very Comfortable & 57.1 & 52.6 & 66.1 \\
\hline \multicolumn{4}{|l|}{ Traumatic Brain Injury } \\
\hline Very Uncomfortable & 9.9 & 14.0 & 1.8 \\
\hline Uncomfortable & 17.5 & 24.6 & 3.5 \\
\hline Neutral & 35.8 & 36.8 & 33.2 \\
\hline Comfortable & 26.9 & 20.2 & 40.4 \\
\hline Very Comfortable & 9.9 & 4.4 & 21.1 \\
\hline \multicolumn{4}{|l|}{ Visual Impairment } \\
\hline Very Uncomfortable & 11.8 & 12.4 & 10.5 \\
\hline Uncomfortable & 17.6 & 21.2 & 10.5 \\
\hline Neutral & 35.3 & 34.5 & 36.8 \\
\hline
\end{tabular}


Table 5, Continued

\begin{tabular}{lccc}
\hline \multicolumn{1}{c}{ Variable } & \% Overall & \% General & \% Special \\
& Sample & Educators & Educators \\
\hline Comfortable & 26.5 & 25.7 & 28.1 \\
Very Comfortable & 8.8 & 6.2 & 14.1 \\
Years of Experience with SWD & & & \\
0 years & 1.2 & 1.7 & .0 \\
1 year & 1.7 & 1.7 & 1.8 \\
2 years & 4.6 & 4.3 & 5.3 \\
3 years & 5.2 & 2.6 & 10.5 \\
4 years & 4.6 & 6.9 & .0 \\
$5-9$ years & 24.3 & 26.7 & 19.3 \\
$10+$ years & 58.4 & 56.1 & 63.1 \\
\hline
\end{tabular}

Note: $* p<.05 ; \mathrm{SWD}=$ Students with Disabilities 
Table 6

Mean Comfort Level with IDEA Disability Categories by Teacher Type

\begin{tabular}{|c|c|c|}
\hline Variable & $\begin{array}{c}\text { General Educators } \\
\text { Mean (SD) }\end{array}$ & $\begin{array}{c}\text { Special Educators } \\
\text { Mean (SD) }\end{array}$ \\
\hline \multicolumn{3}{|l|}{ Comfort Level } \\
\hline Deaf-Blindness & $2.56(1.06)$ & $2.70(1.05)$ \\
\hline Deafness & $2.73(1.01)$ & $2.79(.99)$ \\
\hline Visual Impairment & $2.92(1.10)$ & $3.25(1.15)$ \\
\hline Traumatic Brain Injury & $2.76(1.07)^{*}$ & $3.75(.89)^{*}$ \\
\hline Emotional Disturbance & $3.31(1.05)^{*}$ & $4.23(.76)^{*}$ \\
\hline Hearing Impairment & $3.64(.95)$ & $3.49(.81)$ \\
\hline Orthopedic Impairment & $3.62(.98)$ & $3.82(.85)$ \\
\hline Multiple Disabilities & $3.64(.91)^{*}$ & $4.18(.83)^{*}$ \\
\hline Autism Spectrum Disorder & $3.89(.82)^{*}$ & $4.50(.71)^{*}$ \\
\hline Intellectual Disability & $4.06(.83)^{*}$ & $4.63(.56)^{*}$ \\
\hline Specific Learning Disability & $4.30(.70)^{*}$ & $4.77(.42)^{*}$ \\
\hline Speech or Language & $4.46(.66)$ & $4.48(.91)$ \\
\hline \multicolumn{3}{|l|}{ Impairment } \\
\hline Other Health Impairment & $4.38(.68)^{*}$ & $4.77(.47)^{*}$ \\
\hline \multicolumn{3}{|c|}{ Note: 1 = Very Uncomfortable, $2=$ Uncomfortable, $3=$ Neutral, $4=$ Comfortable, $5=$ Very } \\
\hline \multicolumn{3}{|l|}{ Comfortable } \\
\hline$* p<.05$ & & \\
\hline
\end{tabular}


Table 7

Descriptive Information for Support Variables

\begin{tabular}{|c|c|c|c|}
\hline \multirow{2}{*}{ Variable } & $\%$ Overall & $\%$ General & $\%$ Special \\
\hline & Sample & Educators & Educators \\
\hline \multicolumn{4}{|l|}{ Frequency of Collaboration } \\
\hline Rarely & 3.6 & 5.3 & .0 \\
\hline Occasionally & 11.2 & 14.2 & 5.4 \\
\hline Frequently & 35.5 & 40.7 & 25.0 \\
\hline Very Frequently & 49.7 & 39.8 & 69.6 \\
\hline \multicolumn{4}{|l|}{ With Whom Do Teachers Collaborate } \\
\hline Director of Special Education/Administration & 49.7 & 36.2 & 77.2 \\
\hline Specialists & 50.1 & 42.4 & 63.2 \\
\hline Principals & 68.2 & 69.0 & 66.7 \\
\hline Paraprofessionals & 69.9 & 62.9 & 84.2 \\
\hline School Psychologists & 74.6 & 69.0 & 86.0 \\
\hline Parents & 80.3 & 79.3 & 82.5 \\
\hline General Education Teachers & 80.9 & 76.7 & 89.5 \\
\hline Social Workers & 84.4 & 80.2 & 93.0 \\
\hline Special Education Teachers & 92.5 & 94.8 & 87.7 \\
\hline
\end{tabular}


Table 8

Mean Frequency of Collaboration by Teacher Type

\begin{tabular}{lcc}
\hline Variable & General Educators & Special Educators \\
& Mean (SD) & Mean (SD) \\
\hline Frequency of Collaboration & $4.15(.86)^{*}$ & $4.64(.59)^{*}$ \\
\hline Note: $1=$ Never, 2 = Rarely, $3=$ Occasionally, $4=$ Frequently, $5=$ Very Frequently \\
$* p<.05$
\end{tabular}


Table 9

Open Ended Responses

\begin{tabular}{|c|c|c|c|}
\hline \multirow{2}{*}{ Variable } & $\%$ & $\%$ General & $\%$ Special \\
\hline & Total & Educators & Educators \\
\hline \multicolumn{4}{|l|}{ Difficult Experiences $(\mathrm{N}=133)$} \\
\hline Behaviors & 52.6 & 49.4 & 58.3 \\
\hline Academic Concerns & 14.3 & 17.6 & 8.3 \\
\hline Lack of Support & 13.5 & 10.6 & 18.8 \\
\hline Difficulties with Parents & 10.5 & 8.2 & 14.6 \\
\hline Attention/Engagement/Motivation & 4.5 & 4.7 & 4.2 \\
\hline Technology & 3.0 & 2.4 & 4.2 \\
\hline Other & 12.8 & 15.3 & 8.3 \\
\hline \multicolumn{4}{|l|}{ Positive/Confident Experiences $(\mathrm{N}=120)$} \\
\hline Academic Success & 35.0 & 27.6 & 47.7 \\
\hline Support & 19.2 & 25.0 & 9.1 \\
\hline Social-Emotional Success & 9.2 & 10.5 & 6.8 \\
\hline Behavioral Success & 8.3 & 9.2 & 6.8 \\
\hline Inclusion Working & 4.2 & 5.4 & 2.3 \\
\hline Experience & 3.3 & 3.9 & 2.3 \\
\hline General Success & 10.0 & 5.2 & 18.2 \\
\hline Other & 10.8 & 13.2 & 6.8 \\
\hline \multicolumn{4}{|l|}{ Additional Comments $(\mathrm{N}=24)$} \\
\hline Professional Development/Training/Classes & 33.3 & 44.4 & 0.0 \\
\hline
\end{tabular}


Table 9, Continued

\begin{tabular}{lccc}
\hline Variable & $\%$ & $\%$ General & \% Special \\
& Total & Educators & Educators \\
\hline Admiration for Teaching & & & 50.0 \\
Other Concerns & 41.7 & 38.9 & 50.0 \\
\hline
\end{tabular}




\section{REFERENCES}

Able, H., Sreckovic, M. A., Schultz, T. R., Garwood, J. D., \& Sherman, J. (2015). Views from the trenches: Teacher and student supports needed for full inclusion of students with ASD. Teacher Education and Special Education, 38(1), 44-57.

doi:10.1177/0888406414558096

American Academy of Special Education Professionals. (2006). Roles and Responsibilities of the Special Education Teacher. Retrieved from https://www.naset.org/fileadmin/user_upload/Pro_Development/Roles_Responsibilities_ SPED_Teacher.pdf

Allday, R. A., Neilsen-Gatti, S., \& Hudson, T. M. (2013). Preparation for inclusion in teacher education pre-service curricula. Teacher Education and Special Education, 36(4), 298311. doi: $10.1177 / 0888406413497485$

Alvarez, H. K. (2007). The impact of teacher preparation on responses to student aggression in the classroom. Teaching and Teacher Education, 23(7), 1113-1126. doi:

10.1016/j.tate.2006.10.001

Aron, L., \& Loprest, P. (2012). Disability and the education system. The Future of Children, 97122. Retrieved from https://www.ncbi.nlm.nih.gov/pubmed/22550687

Artino, A. R. (2012). Academic self-efficacy: From educational theory to instructional practice. Perspectives on Medical Education, 1(2), 76-85. doi:10.1007/s40037-012-00125

Bandura, A. (1997). Self-efficacy: The exercise of control. New York, NY: Freeman. Retrieved from https://psycnet.apa.org/record/1997-08589-000 
Blanton, L. P., Pugach, M. C., \& Florian, L. (2011). Preparing general educators to improve outcomes for students with disabilities. Washington, DC: American Association of Colleges of Teacher Education and National Council for Learning Disabilities. Retrieved from https://secure.aacte.org/apps/rl/res_get.php?fid=508\&ref=rl

Blanton, L. P., Boveda, M., Munoz, L. R., \& Pugach, M. C. (2017). The affordances and constraints of special education initial teacher licensure policy for teacher preparation. Teacher Education and Special Education, 40(1), 77-91. doi: 10.1177

Bray-Clark, N., \& Bates, R. (2003). Self-efficacy beliefs and teacher effectiveness: Implications for professional development. Professional Educator, 26(1), 13-22. Retrieved from https://eric.ed.gov/?id=EJ842387

Brownell, M. T., \& Pajares, F. (1999). Teacher efficacy and perceived success in mainstreaming students with learning and behavior problems. Teacher Education and Special Education, 22(3), 154-164. doi: 10.1177/088840649902200303

Buell, M. J., Hallam, R., Gamel-McCormick, M., \& Scheer, S. (1999). A survey of general and special education teachers' perceptions and in-service needs concerning inclusion. International Journal of Disability, Development and Education, 46(2), 143-156. doi:10.1080/103491299100597

Bunch, G., Lupart, J., \& Brown, M. (1997). Resistance and acceptance: Educator attitudes to inclusion of students with disabilities. Ottawa, ON: Social Sciences and Humanities Research Council of Canada. (ERIC Document Reproduction Service No. ED410713). Retrieved from http://files.eric.ed.gov/fulltext/ED410713.pdf 
Burke, K., \& Sutherland, C. (2004). Attitudes toward inclusion: Knowledge vs. experience. Education, 125, 163-172. Retrieved from https://www.researchgate.net/publication/281475142_Attitudes_toward_inclusion_Know ledge_vs_experience

Burrowes, F. A. (2016). Professional development training: In-service teachers' perceptions [ProQuest Information \& Learning]. In Dissertation Abstracts International Section A: Humanities and Social Sciences (Vol. 76, Issue 12-A(E)).

Corcoran, T. B. (1995). Helping Teachers Teach Well: Transforming Professional Development. CPRE Policy Briefs.

Council for Exceptional Children. (2015). What Every Special Educator Must Know: Professional Ethics and Standards. Arlington, VA: CEC

Da Fonte, M. A., \& Barton-Arwood, S. M. (2017). Collaboration of general and special education teachers: perspectives and strategies. Intervention in School and Clinic, 53(2), 99-106. doi:10.1177/1053451217693370

Dawson, H., \& Scott, L. (2013). Teaching students with disabilities efficacy scale: Development and validation. Inclusion, 1(3), 181-196. Retrieved from https://www.researchgate.net/profile/Hadley_Solomon/publication/257945384_Teaching _students_with_disabilities_efficacy_scale_Development_and_validation/links/56b2aeb0 08ae795dd5c7d417/Teaching-students-with-disabilities-efficacy-scale-Development-andvalidation.pdf

deBettencourt, L. U. (1999). General educators' attitudes toward students with mild disabilities and their use of instructional strategies: Implications for training. Remedial and Special Education, 20(1), 27-35. doi:10.1177/074193259902000104 
DeSimone, J. R., \& Parmar, R. S. (2006). Middle school mathematics teachers' beliefs about inclusion of students with learning disabilities. Learning Disabilities Research \& Practice, 21(2), 98-110. doi:10.1111/j.1540-5826.2006.00210.x

Dixon, F. A., Yssel, N., McConnell, J. M., \& Hardin, T. (2014). Differentiated instruction, professional development, and teacher efficacy. Journal for the Education of the Gifted, 37(2), 111-127. doi:10.1177/0162353214529042

Fettig, A., Schultz, T. R., \& Ostrosky, M. M. (2013). Collaborating with parents in using effective strategies to reduce children's challenging behaviors. Young Exceptional Children, 16(1), 30-41. doi: 10.1177/1096250612473127

Frankel, E. B., Hutchinson, N. L., Burbidge, J., \& Minnes, P. (2014). Preservice early childhood educators' and elementary teachers' perspectives on including young children with developmental disabilities: A mixed methods analysis. Journal of Early Childhood Teacher Education, 35(4), 373-391. doi:10.1080/10901027.2014.968300

Fuchs, W. W. (2010). Examining Teachers' Perceived Barriers Associated with Inclusion. SRATE journal, 19(1), 30-35. Received from https://files.eric.ed.gov/fulltext/EJ948685.pdf

Gao, W., \& Mager, G. (2011). Enhancing preservice teachers' sense of efficacy and attitudes toward school diversity through preparation: A case of one US inclusive teacher education program. International Journal of Special Education, 26(2), 92-107. Retrieved from https://eric.ed.gov/?id=EJ937178

Gartin, B. C., \& Murdick, N. L. (2005). IDEA 2004: The IEP. Remedial and Special Education, 26(6), 327-331. doi:10.1177/07419325050260060301 
Gehrke, R. S., \& Cocchiarella, M. (2013). Preservice special and general educators' knowledge of inclusion. Teacher Education and Special Education, 36(3), 204-216. doi:10.1177/0888406413495421

Gibson, S., \& Dembo, M. H. (1984). Teacher efficacy: A construct validation. Journal of Educational Psychology, 76(4), 569-582. doi:10.1037/0022-0663.76.4.569

Gutkin, T.B. \& Curtis, M.J. (2009). School-based consultation: The science and practice of indirect service delivery. In T.B. Gutkin \& C.R. Reynolds (Eds.) The Handbook of School Psychology (4th ed. pp. 591-635). Hoboken, NJ: Wiley.

Hall, T., Vue, G., Strangman, N., \& Meyer, A. (2003). Differentiated instruction and implications for UDL implementation. Wakefield, MA: National Center on Accessing the General Curriculum. Retrieved from http://aem.cast.org/about/publications/2003/ncacdifferentiated-instruction-udl.html

Hemmeter, M. L., Ostrosky, M., \& Fox, L. (2006). Social and emotional foundations for early learning: A conceptual model for intervention. School Psychology Review, 35(4), 583601. Retrieved from https://www.researchgate.net/profile/Michaelene_Ostrosky/publication/228349912_Socia 1_and_emotional_foundations_for_early_learning_A_conceptual_model_for_intervention /links/55005fca0cf2de950a6d6244.pdf

Heneman III, H. G., Kimball, S., \& Milanowski, A. (2006). The Teacher Sense of Efficacy

Scale: Validation Evidence and Behavioral Prediction. WCER Working Paper No. 20067. Wisconsin Center for Education Research (NJ1). Retrieved from https://eric.ed.gov/?id=ED496313 
Hussien, J., \& Al-Qaryouti, I. (2015). General Education Teachers' Perceived Self-Efficacy in Teaching Students with Disabilities in Oman AJIE Asian Journal of Inclusive Education, 3(1), 3-23. Retrieved from https://pdfs.semanticscholar.org/88dc/8b37d6bb130b296c7fd7dc82f20fa0478dac.pdf Illinois Report Card (2019). Demographics. Retrieved from https://www.illinoisreportcard.com/state.aspx?stateid=IL\&source=teachers\&source2=tea cherdemographics

Illinois State Board of Education (2020, February). Guidance and Frequently Asked Questions: Emergency Regulation for the Use of Time Out, Isolated Time Out, and Physical Restraint[PDF]. https://www.isbe.net/Documents/Guidance-FAQs-Time-outRestraint.pdf

Illinois State Board of Education (2019, June). Public School Calendar Guidelines[PDF]. Springfield, Illinois. https://www.isbe.net/Documents/ps_guidelines.pdf

Illinois State Board of Education (2019). Educator License- Special Education. Retrieved from https://www.isbe.net/Pages/Special-Education-Requirements.aspx

Illinois State Board of Education. (n.d.). Renewal and Professional Development for Educators. Retrieved August 7, 2019, from https://www.isbe.net/Pages/Professional-Developmentfor-Educators.aspx

Illinois State University. (2019). SED 101.003: The exceptional learner [course syllabus]. Normal, Illinois: Anne Fulton.

Illinois State University. (2018). Elementary education (B.S. in Ed.) [sample plan of study]. Normal, Illinois: School of Teaching \& Learning. 
Illinois State University. (2018, December 12). About. Retrieved from https://education.illinoisstate.edu/about/

Individuals with Disabilities Education Act, 20 U.S.C. § 1400 (2004)

Kosko, K. W., \& Wilkins, J. L. (2009). General Educators' In-Service Training and Their SelfPerceived Ability to Adapt Instruction for Students with IEPs. Professional Educator, 33(2), n2. Retrieved from https://eric.ed.gov/?id=EJ988196

Lavrakas, P. J. (2008). Encyclopedia of survey research methods (Vols. 1-0). Thousand Oaks, CA: Sage Publications, Inc. doi: 10.4135/9781412963947

Leatherman, J. M., \& Niemeyer, J. A. (2005). Teachers' attitudes toward inclusion: Factors influencing classroom practice. Journal of Early Childhood Teacher Education, 26(1), 23-36. doi: 10.1080/10901020590918979

Leyser, Y., \& Kirk, R. (2004). Evaluating inclusion: An examination of parent views and factors influencing their perspectives. International Journal of Disability, Development and Education, 51(3), 271-285. doi: 10.1080/1034912042000259233

Leyser, Y., Zeiger, T., \& Romi, S. (2011). Changes in self-efficacy of prospective special and general education teachers: Implication for inclusive education. International Journal of Disability, Development and Education, 58(3), 241-255.

doi:10.1080/1034912X.2011.598397

Lohrmann, S., \& Bambara, L. M. (2006). Elementary education teachers' beliefs about essential supports needed to successfully include students with developmental disabilities who engage in challenging behaviors. Research and Practice for Persons with Severe Disabilities, 31(2), 157-173. doi:10.1177/154079690603100208 
Meyers, J. (1973). A consultation model for school psychological services. Journal of School Psychology, 11(1), 5-15. doi:10.1016/0022-4405(73)90003-4

Montgomery, A., \& Mirenda, P. (2014). Teachers' self-efficacy, sentiments, attitudes, and concerns about the inclusion of students with developmental disabilities. Exceptionality Education International, 24(1), 18-32. Retrieved from https://eric.ed.gov/?id=EJ1047835

Moores, D. F. (2011). Waist deep in the big muddy: The Individuals with Disabilities Education Act (IDEA) and No Child Left Behind (NCLB). American Annals of The Deaf, 155(5), 523-525. doi:10.1353/aad.2011.0003

National Center for Education Statistics, X. (2018, April). Characteristics of Public School Teachers. Retrieved April 26, 2020, from https://nces.ed.gov/programs/coe/indicator_clr.asp

National Comprehensive Center for Teacher Quality (2011, February). High-Quality Professional Development for All Teachers: Effectively Allocating Resources[PDF]. Retrieved from https://files.eric.ed.gov/fulltext/ED520732.pdf

National Council for Accreditation of Teacher Education. (2008). Professional standards for the accreditation of teacher preparation institutions. Washington, DC: NCATE. Retrieved from http://www.ncate.org/ /media/Files/caep/accreditation-resources/ncate-standards2008.pdf?la=en

National Council on Teacher Quality (2014, January). Classroom Management[PDF]. https://www.nctq.org/dmsView/Future_Teachers_Classroom_Management_NCTQ_Repo $\mathrm{rt}$

National Education Association. Professional Development. (n.d.). Retrieved from http://www.nea.org/home/30998.htm 
Nichols, L. M., Goforth, A. N., Sacra, M., \& Ahlers, K. (2017). Collaboration to Support Rural Student Social-Emotional Needs. Rural Educator, 38(1), 38-48.

O'Connor, E. A., Yasik, A. E., \& Horner, S. L. (2016). Teachers' Knowledge of Special Education Laws: What Do They Know?. Insights into Learning Disabilities, 13(1), 7-18.

Oliver, R. M., \& Reschly, D. J. (2010). Special education teacher preparation in classroom management: Implications for students with emotional and behavioral disorders. Behavioral Disorders, 35(3), 188-199. doi:10.1177/019874291003500301

Peterson, M., \& Beloin, K. S. (1998). Teaching the inclusive teacher: Restructuring the mainstreaming course in teacher education. Teacher Education and Special Education, 21(4), 306-318. doi:10.1177/088840649802100406

Ponti, C. R., \& Curtis, M. J. (1984, August). Effects of consultation on teachers' attributions for children's school problems. Paper presented at the annual meeting of the American Psychological Association, Toronto.

Poulou, M. (2005). The prevention of emotional and behavioural difficulties in schools: Teachers' suggestions. Educational psychology in practice, 21(1), 37-52. doi:10.1080/02667360500035181

Powers, P. J. (1992). The Effect of Special Education Coursework upon the Preparation of Preservice Teachers. Paper presented at the Annual Meeting of the Northern Rocky Mountain Educational Research Association, Custer State Park, SD. Retrieved from https://eric.ed.gov/?id=ED377183 
President's Commission on Excellence in Special Education, (2002). A New Era: Revitalizing Special Education for Children and Their Families. President's Commission on Excellence in Special Education. Retrieved from http://ectacenter.org/ pdfs/calls/2010/earlypartc/revitalizing_special_education.pd

Rosenzweig, K. (2009). Are Today's General Education Teachers Prepared to Meet the Needs of Their Inclusive Students?. NERA Conference Proceedings 2009. Retrieved from https://opencommons.uconn.edu/cgi/viewcontent.cgi?referer=https://www.theatlantic.co m/education/archive/2017/03/how-teacher-training-hinders-special-needsstudents $/ 518286 / \&$ httpsredir=1\&article=1019\&context=nera_2009

Schwarzer, R., \& Hallum, S. (2008). Perceived teacher self-efficacy as a predictor of job stress and burnout: Mediation analyses. Applied Psychology, 57, 152-171. Retrieved from http://userpage.fu-berlin.de/ health/self/se-teacher_2008.pdf

Seligman, M., \& Darling, R. B. (1997). Ordinary families. Special Children: A Systems Approach to Childhood Disability (2nd ed.). New York, NY: Guilford Press. Retrieved from https://psycnet.apa.org/record/1997-97307-000

Shamina, E., \& Mumthas, N. S. (2018). Classroom Management: Implications for Teacher Preparation Programmes. IOSR Journal Of Humanities And Social Science, 23, 41-44. Retrieved from http://www.iosrjournals.org/iosrjhss/papers/Vol.\%2023\%20Issue1/Version-3/E2301034144.pdf

Sharma, U., \& Nuttal, A. (2016). The impact of training on pre-service teacher attitudes, concerns, and efficacy towards inclusion. Asia-Pacific Journal of Teacher Education, 44(2), 142-155. doi:10.1080/1359866X.2015.1081672 
Strauss, A., \& Corbin, J. (1998). Basics of qualitative research: Techniques and procedures for developing grounded theory(2nded.). Thousand Oaks, CA: Sage Publications.

Swedeen, B. L. (2009). Signs of an inclusive school: A parent's perspective on the meaning and value of authentic inclusion. TEACHING Exceptional Children Plus, 5(3) Article 1. Retrieved from http://escholarship.bc.edu/education/tecplus/vol5/iss3/art1

Tournaki, N., \& Samuels, W. E. (2016). Do graduate teacher education programs change teachers' attitudes toward inclusion and efficacy beliefs? Action in Teacher Education, 38(4), 384-398. Retrieved from https://eric.ed.gov/?id=EJ1122988

Tschannen-Moran, M., \& Hoy, A. W. (2001). Teacher efficacy: Capturing an elusive construct. Teaching and Teacher Education, 17(7), 783-805. doi:10.1016/S0742-051X(01)00036-1

United States Agency for International Development (2011, December). First Principles: Designing Effective Pre-Service Teacher Education Programs Compendium[PDF]. Retrieved from https://pdf.usaid.gov/pdf_docs/PNADZ721.pdf

U.S. Department of Education, National Center for Education Statistics. (2017). Digest of Education Statistics, 2016 (NCES 2017-094), Chapter 2. Retrieved from https://nces.ed.gov/fastfacts/display.asp?id=59

U.S. Department of Education, Office of Special Education Programs, Individuals with Disabilities Education Act (IDEA) database, prepared July, 2017, from https://www2.ed.gov/programs/osepidea/618-data/state-level-datafiles/index.html\#bcc. See Digest of Education Statistics 2017, table 204.30.

Voltz, D. L. (2003). Collaborative infusion: An emerging approach to teacher preparation for inclusive education. Action in Teacher Education, 25(1), 5-13.

Weiner, L. (2006). Challenging deficit thinking. Educational Leadership, 64(1), 42-45. 
Wilkins, T., \& Nietfeld, J. L. (2004). The effect of a school-wide training programme upon teachers' attitudes about inclusion. Journal of Research in Special Educational Needs, 4, 115-121. doi:10.1111/j.1471-3802.2004.00026.x 